\title{
Factors That Control the Reactivity of Cobalt(III)-Nitrosyl Complexes in Nitric Oxide Transfer and Dioxygenation Reactions: A Combined Experimental and Theoretical Investigation
}

\author{
Pankaj Kumar ${ }^{\# \dagger}$, Yong-Min Lee ${ }^{\# \dagger}$, Lianrui Hu${ }^{\ddagger}$, Jianwei Chen ${ }^{\ddagger}$, Young Jun Park ${ }^{\dagger}$, Jiannian \\ Yao $^{\ddagger}$, Hui Chen ${ }^{*}, \neq$, Kenneth D. Karlin ${ }^{*}, \pi$, and Wonwoo Nam ${ }^{*}, \dagger$ \\ tDepartment of Chemistry and Nano Science, Ewha Womans University, Seoul 120-750, Korea \\ 租eijing National Laboratory for Molecular Sciences, CAS Key Laboratory of Photochemistry, \\ Institute of Chemistry, Chinese Academy of Sciences, Beijing 100190, China \\ IDepartment of Chemistry, The Johns Hopkins University, Baltimore, Maryland 21218, United \\ States \\ \# These authors contributed equally to this work.
}

\begin{abstract}
Metal-nitrosyl complexes are key intermediates involved in many biological and physiological processes of nitric oxide (NO) activation by metalloproteins. In this study, we report the reactivities of mononuclear cobalt(III)-nitrosyl complexes bearing $N$-tetramethylated cyclam (TMC) ligands, [(14-TMC)Co $\left.{ }^{\mathrm{III}}(\mathrm{NO})\right]^{2+}$ and $\left[(12-\mathrm{TMC}) \mathrm{Co}^{\mathrm{III}}(\mathrm{NO})\right]^{2+}$, in NO-transfer and dioxygenation reactions. The Co(III)-nitrosyl complex bearing 14-TMC ligand, [(14$\left.\mathrm{TMC}) \mathrm{Co}^{\mathrm{III}}(\mathrm{NO})\right]^{2+}$, transfers the bound nitrosyl ligand to $\left[(12-\mathrm{TMC}) \mathrm{Co}^{\mathrm{II}}\right]^{2+}$ via a dissociative pathway, $\left\{\left[(14-\mathrm{TMC}) \mathrm{Co}^{\mathrm{III}}(\mathrm{NO})\right]^{2+} \rightarrow\{(14-\mathrm{TMC})-\mathrm{Co} \cdots \mathrm{NO}\}^{2+}\right\}$, thus affording [(12$\left.\mathrm{TMC}) \mathrm{Co}^{\mathrm{III}}(\mathrm{NO})\right]^{2+}$ and $\left[(14-\mathrm{TMC}) \mathrm{Co}^{\mathrm{II}}\right]^{2+}$ as products. The dissociation of NO from the $[(14-$ $\left.\mathrm{TMC}) \mathrm{Co}^{\mathrm{III}}(\mathrm{NO})\right]^{2+}$ complex prior to NO-transfer is supported experimentally and theoretically. In contrast, the reverse reaction, which is the NO-transfer from $\left[(12-\mathrm{TMC}) \mathrm{Co}{ }^{\mathrm{III}}(\mathrm{NO})\right]^{2+}$ to $[(14-$ $\left.\mathrm{TMC}) \mathrm{Co}^{\mathrm{II}}\right]^{2+}$, does not occur. In addition to the NO-transfer reaction, dioxygenation of [(14TMC)Co $\left.{ }^{\mathrm{III}}(\mathrm{NO})\right]^{2+}$ by $\mathrm{O}_{2}$ produces $\left[(14-\mathrm{TMC}) \mathrm{Co}^{\mathrm{II}}\left(\mathrm{NO}_{3}\right)\right]^{+}$, which possesses an O,O-chelated nitrato ligand and where, based on an experiment using ${ }^{18} \mathrm{O}$-labeled $\mathrm{O}_{2}$, two of the three O-atoms in the $\left[(14-\mathrm{TMC}) \mathrm{Co}^{\mathrm{II}}\left(\mathrm{NO}_{3}\right)\right]^{+}$product derive from $\mathrm{O}_{2}$. The dioxygenation reaction is proposed to occur via a dissociative pathway, as proposed in the NO-transfer reaction, and via the formation of a $\mathrm{Co}(\mathrm{II})-$ peroxynitrite intermediate, based on the observation of phenol ring nitration. In contrast,
\end{abstract}

\footnotetext{
*Corresponding Authors: chenh@iccas.ac.cn, karlin@jhu.edu,wwnam@ewha.ac.kr. ASSOCIATED CONTENT

Supporting Information

The Supporting Information is available free of charge on the ACS Publications website at DOI: 10.1021/jacs.6b04040.

Procedure for synthesis of $\mathbf{1}$, spectroscopic data for $\mathbf{1}$ and $\mathbf{6}$, reactivity data for $\mathbf{1}$, crystallographic data for $\mathbf{6}$, computational details, and Cartesian coordinates of species in reactions (PDF)

Crystallographic data for $\left[(14-\mathrm{TMC}) \mathrm{Co}^{\mathrm{II}}\left(\mathrm{NO}_{3}\right)\right](\mathrm{BPh} 4)$, complex 6 (CIF)

The authors declare no competing financial interest.
} 
$\left[(12-\mathrm{TMC}) \mathrm{Co}^{\mathrm{III}}(\mathrm{NO})\right]^{2+}$ does not react with $\mathrm{O}_{2}$. Thus, the present results demonstrate unambiguously that the NO-transfer/dioxygenation reactivity of the cobalt(III)-nitrosyl complexes bearing TMC ligands is significantly influenced by the ring size of the TMC ligands and/or the spin state of the cobalt ion.

\section{Graphical abstract}

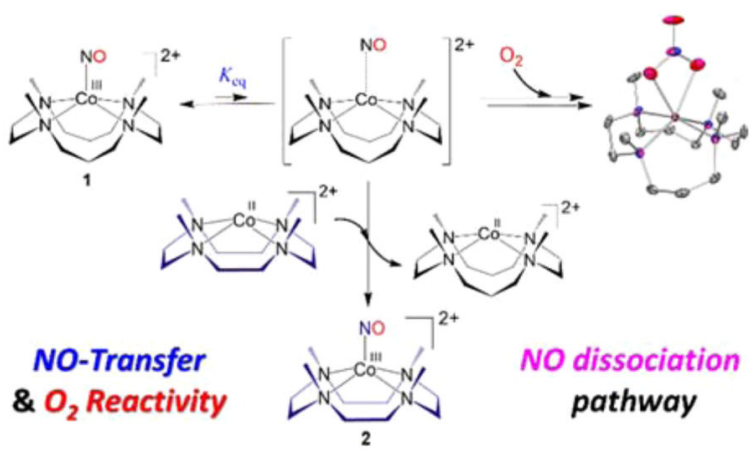

\section{INTRODUCTION}

As a free radical nitrogen-oxide molecule, NO (nitric oxide, nitrogen monoxide) is known to play diverse roles in biological processes. ${ }^{1}$ In natural systems, the biosynthesis of NO and its various biological and physiological reactions come about through the interaction with metalloproteins of iron and/or copper. ${ }^{2}$ Thus, reactions of NO through its coordination with transition metal centers are of great interest for chemists and biochemists. ${ }^{3}$ In addition, there is a long history of the study of transition metal-NO interactions, to understand fundamental aspects of the structure, bonding, and reactivity of metal-NO species. ${ }^{3}$

There are a few reports on the intermolecular transfer of metal-coordinated ligands such as $\mathrm{O}_{2}, \mathrm{O}^{2-}$, and $\mathrm{NO}, 4,5$ and it has been shown that NO-transfer between two metal complexes can occur, depending on the NO-to-metal binding constant, ligand geometry, and metal oxidation state. The prior literature on metal complex NO-transfer chemistry suggests at least two proposed pathways, but no unambiguous mechanistic conclusion has ever been reached. In this regard, one of the early examples involves the acid-promoted intermolecular transfer of $\mathrm{NO}$ from $\mathrm{Co}^{\mathrm{II}}$ to $\mathrm{Cr}^{\mathrm{II}}$, involving the formation of a labile aqua complex at lower $\mathrm{pH}^{5 \mathrm{a}}$ In another case, protonation of an axial ligand transforms the geometry of coordinated NO toward a more bent conformation, allowing NO-transfer. ${ }^{5 \mathrm{~b}}$ Caulton and co-workers undertook a detailed investigation of nitrosyl transfer from $\mathrm{Co}(\mathrm{NO})(\mathrm{dmgH})_{2}(\mathrm{dmgH}=$ monoanion of dimethylglyoxime $\left.\left(\mathrm{dmgH}_{2}\right)\right)$ to the various metal complexes of $\mathrm{Fe}, \mathrm{Co}, \mathrm{Ni}$, and $\mathrm{Ru} .{ }^{5 \mathrm{c}}$ For the first time, they suggested a $\mu$-bridged nitrosyl formation prior to the transfer of NO. A dissociative pathway of NO-transfer was described for a $\mathrm{Co}(\mathrm{NO})(\mathrm{dmgH})_{2}$ complex in the presence of hemoglobin $(\mathrm{Hb})$, with first dissociation of $\mathrm{NO}$ followed by formation of HbNO. ${ }^{6}$ Lippard and co-workers also suggested a dissociative pathway of NOtransfer from manganese to iron bearing a tropocoronand ligand framework. ${ }^{7}$ Recently, intermolecular transfer of a ruthenium-bound nitrosyl to a coordinatively unsaturated iron complex was reported to occur through a heterobimetallic $\mu$-bridged nitrosyl intermediate. ${ }^{8}$ 
Thus, on the basis of insights coming from all of these reactions, two mechanisms have been proposed (Scheme 1, M and $\mathrm{M}^{\prime}$ are different metal ions): one is a dissociative pathway of NO-transfer (Scheme 1a), ${ }^{6}$ and the other involves an associative pathway (Scheme 1b). ${ }^{8}$

In addition to the mechanism described above, the study of the reactions of both $\mathrm{NO}$ and $\mathrm{O}_{2}$ or their derivatives with transition metal complexes has attracted much attention. Since the coordination chemistry of metal-nitrosyl complexes has a long history, various reactions with metal-nitrosyl complexes have been reported. ${ }^{3}$ These species can be exceedingly stable, but many of them do in fact react with $\mathrm{O}_{2}$, and metal nitrite or nitrate complexes are frequently obtained as the products, depending on the system at hand. ${ }^{9-11}$ Clarkson and Basolo described for the first time the chemistry of certain cobalt-nitrosyl complexes, proposing that a peroxynitrite $\left(\mathrm{PN},{ }^{-} \mathrm{OON}=\mathrm{O}\right)$ intermediate may form and thermally decay to give a cobalt nitrite complex product. ${ }^{9}$ Many other examples supported this work. ${ }^{10}$ In the case of dinitrosyl-iron species (DNICs), the metal-nitrosyl complex reacts with $\mathrm{O}_{2}$ to form a metal nitrate complex as the final product, putatively via the isomerization of a PN intermediate. ${ }^{11}$ It should be noted that, in aqueous chemistry, (i) peroxynitrite is the diffusion-controlled reaction product of $\mathrm{NO}$ plus superoxide anion $\left(\mathrm{O}_{2}{ }^{--}\right),{ }^{12}$ and (ii) the primary decomposition product of peroxynitrous acid is nitric acid derived from a very fast isomerization reaction. ${ }^{13}$

In what is turning out to be chemistry that is complementary, the study of the reactivity of metal- $\mathrm{O}_{2}$ species with $\mathrm{NO}$ has been of great interest, ${ }^{14,15}$ in part due to its relevance in understanding the chemistry involved in the enzyme NO dioxygenase (NOD). NOD activity aids the maintenance of appropriate cellular NO balance by converting excesses to give the biologically benign nitrate ion. ${ }^{13}$ Thus, oxyhemoglobin, oxymyoglobin, and bacterial heme$\mathrm{O}_{2}$ adducts ("oxy-ferrous" or formally $\mathrm{Fe}^{\mathrm{III}}-$ superoxide) are NODs. These reactions are thought to proceed through $\mathrm{Fe}^{\mathrm{III}}-\mathrm{PN}$ intermediates, prior to nitrate formation; ${ }^{14,15}$ nitrogen dioxide $\left(\mathrm{NO}_{2}\right)$ may otherwise be released. ${ }^{16}$ Thus, metal-PN generation may occur via metal- $\mathrm{O}_{2}$ plus $\mathrm{NO}$ or metal-NO plus $\mathrm{O}_{2}$ reactions, as shown recently in coordination complexes of chromium, ${ }^{17 \mathrm{a}, \mathrm{b}}$ iron, ${ }^{17 \mathrm{c}}$ copper, ${ }^{18}$ hemes, ${ }^{19}$ and cobalt-porphyrins. ${ }^{20}$

Nam and co-workers have described an extensive series of first-row transition metalsuperoxo, -peroxo, and -oxo species bearing $N$-tetramethylated cyclam (TMC) ligands, ${ }^{21}$ in which structure, bonding, and reactivity of the metal-oxygen complexes are greatly influenced by the ring size of the macrocycles. In relation to the NOD reactivity, TMC chromium-superoxo, chromium-peroxo, and iron-peroxo complexes were treated with NO or nitrosonium $\left(\mathrm{NO}^{+}\right)$ion, and in all cases metal-peroxynitrite intermediates were implicated as transient intermediates, leading to the formation of nitrite or nitrate metal complexes as final products. ${ }^{17}$

We report herein for the first time that the NO-transfer and dioxygen reactivity of $\mathrm{Co}^{\mathrm{III}}$ nitrosyl complexes bearing TMC ligands are tuned by the ring size of the supporting ligands and/or the spin state of $\mathrm{Co}^{\mathrm{II}}$ ion. More specifically, a new $\mathrm{Co}^{\mathrm{III}}$-nitrosyl complex bearing a 14-TMC ligand, [(14-TMC)-Co $\left.{ }^{\mathrm{III}}(\mathrm{NO})\right]^{2+}(\mathbf{1})(14-\mathrm{TMC}=1,4,8,11$-tetramethy-1,4,8,11tetraazacyclotetradecane), is generated and characterized spectroscopically and structurally. Its reactivities are investigated in the NO-transfer reaction from 1 to $\left[(12-\mathrm{TMC})-\mathrm{Co}^{\mathrm{II}}\right]^{2+}(12-$ 
TMC $=1,4,7,10$-tetramethyl-1,4,7,10-tetraazacyclododecane) and in the reaction with $\mathrm{O}_{2}$, and are compared with those of the previously reported $\left[(12-\mathrm{TMC}) \mathrm{Co}^{\mathrm{III}}(\mathrm{NO})\right]^{2+}(\mathbf{2})$ complex. ${ }^{22}$ We propose the mechanism of the NO-transfer and dioxygen reactions as occurring via a dissociative pathway. Density functional theory (DFT) calculations further clarify the detailed mechanism of NO-transfer from 1 to $\left[(12-\mathrm{TMC})-\mathrm{Co}^{\mathrm{II}}\right]^{2+}$, supporting the experimental implication of a NO dissociation pathway.

\section{RESULTS AND DISCUSSION}

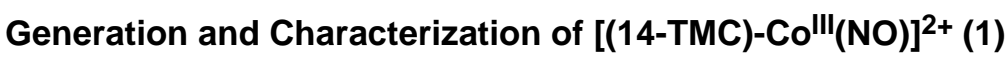

The $\mathrm{Co}^{\mathrm{III}}-$ nitrosyl complex bearing a 14-TMC ligand, [(14-TMC)Co $\left.{ }^{\mathrm{III}}(\mathrm{NO})\right]^{2+}(\mathbf{1})$, was synthesized by adding $\mathrm{NO}_{(\mathrm{g})}$ to a solution of $\left[(14-\mathrm{TMC}) \mathrm{Co}^{\mathrm{II}}\right]^{2+}$. As shown in Figure 1a, addition of $\mathrm{NO}$ (1 equiv) to the solution of $\left[(14-\mathrm{TMC}) \mathrm{Co}^{\mathrm{II}}\right]^{2+}$ under an $\mathrm{Ar}$ atmosphere in $\mathrm{CH}_{3} \mathrm{CN}$ at $-40{ }^{\circ} \mathrm{C}$ resulted in the formation of a new species with absorption bands at 395 $\mathrm{nm}\left(\varepsilon=690 \mathrm{M}^{-1} \mathrm{~cm}^{-1}\right)$ and $555 \mathrm{~nm}\left(\varepsilon=220 \mathrm{M}^{-1} \mathrm{~cm}^{-1}\right)$, which are similar to those of [(12TMC)-Co $\left.{ }^{\mathrm{III}}(\mathrm{NO})\right]^{2+}(2 ; 368$ and $538 \mathrm{~nm})$ and $\left[(13-\mathrm{TMC})-\mathrm{Co}^{\mathrm{III}}(\mathrm{NO})\right]^{2+}(375$ and $550 \mathrm{~nm}){ }^{22}$ A solution IR spectrum of 1 exhibited a characteristic peak at $1715 \mathrm{~cm}^{-1}$ (Figure 1a, inset), which is almost identical to NO stretching bands of $2\left(1712 \mathrm{~cm}^{-1}\right)$ and [(13$\left.\mathrm{TMC}) \mathrm{Co}^{\mathrm{III}}(\mathrm{NO})\right]^{2+}\left(1716 \mathrm{~cm}^{-1}\right) .{ }^{22}$ An electron paramagnetic resonance (EPR) spectrum of $\mathbf{1}$ is silent, suggesting the trivalency of the cobalt center in $\mathbf{1}$ (Figure 1b). In addition to EPR, a ${ }^{1} \mathrm{H}$ NMR spectrum of $\mathbf{1}$ supports that the oxidation state of cobalt center in $\mathbf{1}$ is $3+$ with a spin state of $S=0$ (Figure S1 in Supporting Information (SI)). The results described above demonstrate that the formally $\mathrm{Co}^{\mathrm{III}}\left(\mathrm{NO}^{-}\right)$or $\{\mathrm{Co}(\mathrm{NO})\}^{8}$ was formed in the reaction of [(14TMC)Co $\left.{ }^{\mathrm{II}}\right]^{2+}$ with NO.

In addition to the above spectroscopic characterization, the electronic structure of the Co(III)-nitrosyl complexes was investigated by carrying out DFT calculations to understand NO binding to the cobalt center, revealing that both $\mathbf{1}$ and $\mathbf{2}$ have an open-shell singlet ground state (Figure 2). The DFT-optimized geometry of $\mathbf{2}$ is in a good agreement with the previously reported X-ray crystal structure of $\mathbf{2}-\left(\mathrm{ClO}_{4}\right)_{2}$ (Figure $\left.2 \mathrm{c}\right) .{ }^{22}$ The triplet states of $\mathbf{1}$ and 2 are 3.5 and $0.3 \mathrm{kcal} / \mathrm{mol}$ higher than the corresponding singlet states, respectively. Moreover, the nearly linear $\mathrm{Co}(1)-\mathrm{N}(5)-\mathrm{O}(1)$ geometry in the DFT-optimized structure of the triplet state of $\mathbf{2}$ suggests that the triplet state is not likely to be the ground state. We also calculated the quintet states of $\mathbf{1}$ and $\mathbf{2}$, which are higher in energy than the corresponding ground singlet states of 1 and 2 by 6.9 and $14.0 \mathrm{kcal} / \mathrm{mol}$, respectively. The calculated $\mathrm{Co}(1)-\mathrm{N}(5)-\mathrm{O}(1)$ angle of about $150^{\circ}$ in the quintet state of $\mathbf{2}$ is also inconsistent with the $\mathrm{X}$-ray crystal structure of $\mathbf{2}-\left(\mathrm{ClO}_{4}\right)_{2}$. The open-shell character of the singlet states of $\mathbf{1}$ and $\mathbf{2}$ is depicted by the two singly occupied orbitals as shown in Figure 2, in which the two unpaired electrons couple antiferromagnetically. Thus, all spectroscopic data (Figure 1) with the DFT-optimized structure (Figure 2) support that $\mathbf{1}$ is a cobalt(III)-nitrosyl complex binding the NO ligand in an end-on fashion.

\section{NO-Transfer Reactions}

The reactivity of the $\mathrm{Co}^{\mathrm{III}}$-nitrosyl complexes was investigated in NO-transfer reactions under an $\mathrm{Ar}$ atmosphere in $\mathrm{CH}_{3} \mathrm{CN}$ at $-40{ }^{\circ} \mathrm{C}$. Upon addition of one equiv of [(12- 
$\left.\mathrm{TMC}) \mathrm{Co}^{\mathrm{II}}\right]^{2+}$ to a $\mathrm{CH}_{3} \mathrm{CN}$ solution of [(14-TMC)Co $\left.{ }^{\mathrm{III}}(\mathrm{NO})\right]^{2+}(\mathbf{1}$, black line in Figure 3a), a new UV-vis spectrum was obtained immediately (blue line in Figure 3a), and following this, the blue line spectrum slowly changed to the red line spectrum with an absorption band at $368 \mathrm{~nm}$ (Figure 3a, inset, red circles), which corresponds to the characteristic absorption band of $\left[(12-\mathrm{TMC}) \mathrm{Co}^{\mathrm{III}}(\mathrm{NO})\right]^{2+}(2)$ (Scheme 2 , reaction a). ${ }^{22}$ The spectrum with blue line was confirmed to be the sum of UV-vis spectra of 1 and [(12-TMC)Co $\left.{ }^{\mathrm{II}}\right]^{2+}$ (Figure S2a in $\mathrm{SI})$. It should be noted that, in the absence of $\left[(12-\mathrm{TMC}) \mathrm{Co}^{\mathrm{II}}\right]^{2+}$, no spectral change was observed (Figure 3a, inset, black circles), indicating that $\mathbf{1}$ is highly stable under an Ar atmosphere at $-40{ }^{\circ} \mathrm{C} .{ }^{23}$ The final spectrum (red line in Figure 3a), which was confirmed to be the sum of those spectra of 2 and [(14-TMC)Co $\left.{ }^{\mathrm{II}}\right]^{2+}$ (Figure S2b in SI), indicating that 2 was generated quantitatively ( $>95 \%$ ) based on the $\varepsilon\left(\mathrm{M}^{-1} \mathrm{~cm}^{-1}\right)$ value at $368 \mathrm{~nm}$ due to 2 , since the $\left[(14-\mathrm{TMC}) \mathrm{Co}^{\mathrm{II}}\right]^{2+}$ product has almost no absorption at $368 \mathrm{~nm}$ as shown in Figure 1a (pink line). This NO-transfer from $\mathbf{1}$ to $\left[(12-\mathrm{TMC}) \mathrm{Co}^{\mathrm{II}}\right]^{2+}$ for the formation of $\mathbf{2}$ was confirmed by addition of [(12-TMC)Co $\left.{ }^{\mathrm{II}}\right]^{2+}$ to a solution of $\mathbf{1}$ in increments of 0.2 equiv in $\mathrm{CH}_{3} \mathrm{CN}$ at $-40{ }^{\circ} \mathrm{C}$ (Figure 4). The spectroscopic titration at $368 \mathrm{~nm}$ (Figure 4, inset) for the formation of $\mathbf{2}$ indicates that the reaction stoichiometry of $\mathbf{1}$ and $\left[(12-\mathrm{TMC}) \mathrm{Co}^{\mathrm{II}}\right]^{2+}$ is $1: 1$, and 1 equiv of [(12-TMC)-Co $\left.{ }^{\mathrm{II}}\right]^{2+}$ is required for the full conversion of $\mathbf{1}$ to $\mathbf{2}$. In contrast to the NO-transfer from 1 to $\left[(12-\mathrm{TMC}) \mathrm{Co}^{\mathrm{II}}\right]^{2+}$, no NO-transfer from 2 to $\left[(14-\mathrm{TMC}) \mathrm{Co}^{\mathrm{II}}\right]^{2+}$ was observed (Figure S3 in SI), indicating that the binding affinity of NO to [(12$\left.\mathrm{TMC}) \mathrm{Co}^{\mathrm{II}}\right]^{2+}$ is higher than that to $\left[(14-\mathrm{TMC}) \mathrm{Co}^{\mathrm{II}}\right]^{2+}$. In addition, the formation rates of $\mathbf{1}$ and 2 in the reactions of $\left[(14-\mathrm{TMC}) \mathrm{Co}^{\mathrm{II}}\right]^{2+}$ and $\left[(12-\mathrm{TMC}) \mathrm{Co}^{\mathrm{II}}\right]^{2+}$ with $\mathrm{NO}$, respectively, were determined to be the second-order rate constants of 3.3(3) and 12(1) $\mathrm{M}^{-1} \mathrm{~s}^{-1}$, respectively (Figure S4 in SI), indicating that the formation rate of $\mathbf{2}$ is $\sim 4$ times faster than that of $\mathbf{1}$.

The intermolecular NO-transfer from 1 to $\left[(12-\mathrm{TMC})-\mathrm{Co}^{\mathrm{II}}\right]^{2+}$ was further confirmed by examination of the associated solution IR, ESI-MS, and EPR spectroscopies. According to solution IR measurements, a peak at $1715 \mathrm{~cm}^{-1}$ for the NO stretching frequency of $\mathbf{1}$ (Figure 1a, inset) was changed to $1712 \mathrm{~cm}^{-1}$ due to formation of 2 (Figure 5a), which is identical to the NO stretching frequency of $2,,^{22}$ upon addition of [(12-TMC) $\left.\mathrm{Co}^{\mathrm{II}}\right]^{2+}$ to a solution of $\mathbf{1}$. An ESI-MS of the reaction solution exhibited prominent mass peaks at $m / z=416.0,414.2$, and 178.1 (Figure $3 \mathrm{~b}$ ), whose mass and isotopic distribution patterns correspond to [(12$\left.\mathrm{TMC}^{\mathrm{C}} \mathrm{Co}^{\mathrm{III}}(\mathrm{NO})\left(\mathrm{ClO}_{4}\right)\right]^{+}(\mathrm{calcd} \mathrm{m} / z=416.1),\left[(14-\mathrm{TMC}) \mathrm{Co}^{\mathrm{II}}\left(\mathrm{ClO}_{4}\right)\right]^{+}(\mathrm{calcd} \mathrm{m} / z=414.1)$, and $\left[(14-\mathrm{TMC}) \mathrm{Co}^{\mathrm{II}}\left(\mathrm{CH}_{3} \mathrm{CN}\right)\right]^{2+}($ calcd $m / z=178.1)$, respectively, indicating that 2 and [(14TMC)Co $\left.\mathrm{Co}^{\mathrm{II}}\right]^{2+}$ were formed in this reaction. An EPR spectrum of the final reaction solution revealed that a high-spin cobalt(II) complex formed, which is identical to that of [(14TMC)Co $\left.{ }^{\mathrm{II}}\right]^{2+}$ (see Figure 1b). Based on the above spectroscopic characterization of the reaction solution, we further conclude that 2 and $\left[(14-\mathrm{TMC}) \mathrm{Co}^{\mathrm{II}}\right]^{2+}$ were produced by reacting 1 with [(12-TMC) $\left.\mathrm{Co}^{\mathrm{II}}\right]^{2+}$ (Scheme 2, reaction a).

\section{Mechanistic Insight into the NO-Transfer Reaction}

We then investigated the concentration effect of $\left[(12-\mathrm{TMC}) \mathrm{Co}^{\mathrm{II}}\right]^{2+}$ on the NO-transfer reaction of 1 to $\left[(12-\mathrm{TMC}) \mathrm{Co}^{\mathrm{II}}\right]^{2+}$ and found that the NO-transfer reaction was independent of the $\left[(12-\mathrm{TMC}) \mathrm{Co}^{\mathrm{II}}\right]^{2+}$ concentration (Figure S5 in SI). As shown in Figure 3a, the reaction of $\mathbf{1}$ with $\left[(12-\mathrm{TMC}) \mathrm{Co}^{\mathrm{II}}\right]^{2+}$ did not afford the formation of a new associated 
intermediate, indicating that this reaction does not occur via an associative pathway (vide supra). In addition, there is an equilibrium between 1 and a cage molecule, $\{(14-$ $\mathrm{TMC}) \mathrm{Co} \cdots \mathrm{NO}^{2+}$, prior to the reaction with $\left[(12-\mathrm{TMC}) \mathrm{Co}^{\mathrm{II}}\right]^{2+}$, as shown in Scheme 3 . Since the first step of the reaction (Scheme 3, pathway a) is the rate-determining step, the overall rate constant $\left(k_{\mathrm{obs}}\right)$ of $8.2(7) \times 10^{-4} \mathrm{~s}^{-1}$ (Figure 3a, inset) is equal to the rate constant of the dissociation to the cage molecule $\left(k_{1}\right)$. The second-order rate constant of 3.3(3) $\mathrm{M}^{-1}$ $\mathrm{s}^{-1}$ determined in the reaction of [(14-TMC)Co $\left.\mathrm{Co}^{\mathrm{II}}\right]^{2+}$ with $\mathrm{NO}$ (Figure S4 in SI) indicates that the rate of re-formation to $1\left(k_{-1}\right)$ might be at least more than $10^{3}$-fold faster than that of dissociation to the cage molecule $\left(k_{1}\right)$. In addition, the rate of the formation of $\mathbf{2}\left(k_{2}\right.$; Scheme 3 , pathway $b$ ) might be faster than that of the re-formation of $\mathbf{1}\left(k_{-1}\right)$, because the NO binding affinity of $\left[(12-\mathrm{TMC}) \mathrm{Co}^{\mathrm{II}}\right]^{2+}$ is greater than that of $\left[(14-\mathrm{TMC}) \mathrm{Co}^{\mathrm{II}}\right]^{2+}$. Therefore, as shown in Scheme 3, we propose that the NO-transfer reaction of $\mathbf{1}$ with $\left[(12-\mathrm{TMC}) \mathrm{Co}^{\mathrm{II}}\right]^{2+}$ occurs via a dissociative pathway 6,7 through a putative cage molecule, $\{(12-$ $\left.\mathrm{TMC}) \mathrm{Co}^{\mathrm{II}} \cdots \mathrm{NO}\right\}^{2+}$, and the order of rates for each step is $k_{2}>k_{-1} \gg k_{1}$.

\section{DFT Calculations for Mechanistic Insight into the NO-Transfer Reaction of 1 with [(12- TMC)Co"ll $]^{2+}$}

DFT calculations were conducted to investigate why a dissociative cage molecule mechanism is preferred to an associative mechanism in the NO-transfer from 1 to [(12TMC)Co $\left.{ }^{\mathrm{II}}\right]^{2+}$. First, for the dissociative pathway, the calculated NO dissociation profile starting from the ground singlet state of $\mathbf{1}$ is depicted in Figure 6 . We can see that the barrier of NO dissociation is only $3.2 \mathrm{kcal} / \mathrm{mol}$. This small barrier is associated with a large stretching of Co-NO bond in a NO-dissociative transition state (TS) by about $1.4 \AA$ from $\mathbf{1}$, as shown in Figure 7. After NO dissociation from 1, the NO coordination to [(12$\left.\mathrm{TMC}) \mathrm{Co}^{\mathrm{II}}\right]^{2+}$ is found to be a barrierless process.

In comparison, the NO-transfer profile from 1 to $\left[(12-\mathrm{TMC}) \mathrm{Co}^{\mathrm{II}}\right]^{2+}$ for the associative pathway is shown in Figure 8. Here, we employed a model of $\left\{\left[(14-\mathrm{TMC}) \mathrm{Co}^{\mathrm{III}}-\mathrm{NO}-\right.\right.$ $\left.\left.\mathrm{Co}^{\mathrm{II}}(12-\mathrm{TMC})\right]\left(\mathrm{ClO}_{4}\right)_{3}\right\}^{+}$. In the absence of three perchlorate counterions, the [(14TMC)Co $\left.{ }^{\mathrm{III}}-\mathrm{NO}-\mathrm{Co}^{\mathrm{II}}(12-\mathrm{TMC})\right]^{4+}$ is not stable, and the $\left[(12-\mathrm{TMC}) \mathrm{Co}^{\mathrm{II}}\right]^{2+}$ fragment dissociates from the $\left[(14-\mathrm{TMC}) \mathrm{Co}^{\mathrm{III}}(\mathrm{NO})\right]^{2+}$ fragment, possibly due to the Coulombic repulsion between the two +2 charged Co fragments. As shown in Figure 8, the associative mechanism is initiated from the $\mu$-NO-bridged intermediate 3 by NO-transfer from the [(14$\left.\mathrm{TMC}) \mathrm{Co}^{\mathrm{II}}\right]^{2+}$ fragment to the $\left[(12-\mathrm{TMC})-\mathrm{Co}^{\mathrm{II}}\right]^{2+}$ fragment, resulting in intermediate 4 with an $\mathrm{NO}$ coordinated to the $\left[(12-\mathrm{TMC}) \mathrm{Co}^{\mathrm{II}}\right]^{2+}$ fragment by its $\mathrm{O}$-atom. Then, $\mathrm{O}$ - to $\mathrm{N}$-atom coordination isomerization occurs, leading to the final NO-transfer product $\mathbf{5}$. The highestlying TS ( $\mathbf{T S}_{4-5}$ ) along the reaction profile is $9.3 \mathrm{kcal} / \mathrm{mol}$ higher than $\mathbf{3}$, which is significantly higher than the $3.2 \mathrm{kcal} / \mathrm{mol}$ barrier in the dissociative pathway, indicating that the latter is actually the more preferred NO-transfer pathway from $\mathbf{1}$ to $\left[(12-\mathrm{TMC})-\mathrm{Co}^{\mathrm{II}}\right]^{2+}$.

Considering the experimental results observed in solution IR and EPR experiments and taking account of the UV-vis kinetic measurements as well as the computational results, the reaction for NO-transfer is likely to occur via a dissociative pathway through a cage molecule prior to NO dissociation from cobalt center. Therefore, it is highly logical to assume that NO-transfer between 1 and $\left[(12-\mathrm{TMC}) \mathrm{Co}^{\mathrm{II}}\right]^{2+}$ takes place through $\mathrm{NO}$ 
dissociation pathway as shown in Scheme 3. The affinity of cobalt ion toward NO is the key factor and controls the mode of NO-transfer mechanism, which can be explained on the basis of the TMC ring size and the spin state of $\mathrm{Co}^{\mathrm{II}}$ ion. To understand the TMC ring size effect, we compare the rate of the formation of $\mathbf{1}$ and $\mathbf{2}$ (vide supra), suggesting the formation rate of $\mathbf{2}$ is $\sim 4$ time faster than that of $\mathbf{1}$ (Figure S4 in SI). This explains the high affinity of $\mathbf{2}$ toward NO and suggests a higher stability of $\mathbf{2}$ compared to $\mathbf{1}$. Our computational results for $\mathbf{1}$ and $\mathbf{2}$ also directly showed their relative stabilities, showing that $\mathbf{2}$ is more stable than 1 by $3.6 \mathrm{kcal} / \mathrm{mol}$ in Gibbs free energy. Therefore, this difference of the stability of $\mathbf{1}$ and $\mathbf{2}$ is the thermodynamic driving force for the NO-transfer reaction from $\mathbf{1}$ bearing a larger TMC ligand to $\left[(12-\mathrm{TMC}) \mathrm{Co}^{\mathrm{II}}\right]^{2+}$ bearing a smaller TMC ligand.

The spin state of the cobalt ions in $\left[(12-\mathrm{TMC}) \mathrm{Co}^{\mathrm{II}}\right]^{2+}$ and $\left[(14-\mathrm{TMC}) \mathrm{Co}^{\mathrm{II}}\right]^{2+}$ was also determined. An X-band EPR spectrum of $\left[(12-\mathrm{TMC}) \mathrm{Co}^{\mathrm{II}}\right]^{2+}$ shows signals at $g_{1}=2.34, g_{2}=$ 2.31 , and $g_{3}=2.05$, which are very typical for low $\operatorname{spin}(S=1 / 2) \mathrm{Co}^{\mathrm{II}}$ species (Figure $5 \mathrm{~b}$, black line), while that of $\left[(14-\mathrm{TMC}) \mathrm{Co}^{\mathrm{II}}\right]^{2+}$ exhibits signals at $g_{1}=7.4, g_{2}=2.17$, and $g_{3}=$ 1.50 , which are the characteristic values of a high-spin $(S=3 / 2) \mathrm{Co}^{\mathrm{II}}$ species (Figure $1 \mathrm{~b}$, pink line). This ground spin state difference between $\left[(12-\mathrm{TMC}) \mathrm{Co}^{\mathrm{II}}\right]^{2+}$ and $[(14-$ $\left.\mathrm{TMC}) \mathrm{Co}^{\mathrm{II}}\right]^{2+}$ was also sensitively monitored in our DFT calculations (Figure S6 in SI). The spin state of the cobalt centers influences the reactivity toward the NO coordination, indicating that $\left[(12-\mathrm{TMC}) \mathrm{Co}^{\mathrm{II}}\right]^{2+}$ (low-spin $S=1 / 2$ ) has very high affinity for NO, compared to the [(14-TMC) $\left.\mathrm{Co}^{\mathrm{II}}\right]^{2+}$ species (high-spin $S=3 / 2$ ). Consequently, as the ring size of the TMC ligand increases, the affinity of the cobalt center toward NO coordination decreases, and the reactivity of $\mathrm{Co}^{\mathrm{III}}$-nitrosyl increases, which hence facilitates the NOtransfer from 1 to $\left[(12-\mathrm{TMC}) \mathrm{Co}^{\mathrm{II}}\right]^{2+}$.

\section{Dioxygenation Reactivity of Co(III)-Nitrosyl Complex, 1}

In addition to the NO-transfer reactions, the $\mathrm{O}_{2}$ reactivity of $\left[14-(\mathrm{TMC}) \mathrm{Co}^{\mathrm{III}}(\mathrm{NO})\right]^{2+}(\mathbf{1})$ was investigated. Upon addition of an excess of $\mathrm{O}_{2}$ to a $\mathrm{CH}_{3} \mathrm{CN}$ solution of $\mathbf{1}$, the absorption band at $395 \mathrm{~nm}$ due to $\mathbf{1}$ decayed with first-order kinetics (Figure 9), indicating that $\mathbf{1}$ reacted with $\mathrm{O}_{2}$, whereas $\mathbf{2}$ did not show any reactivity toward $\mathrm{O}_{2}$ as reported previously. ${ }^{22}$ The first-order rate constant was determined to be $7.6(7) \times 10^{-4} \mathrm{~s}^{-1}$ (Figure S7 in SI), which is quite similar to that obtained in the NO-transfer reaction from 1 to $\left[(12-\mathrm{TMC}) \mathrm{Co}^{\mathrm{II}}\right]^{2+}$ (vide supra). We also found that the reaction rate of $\mathbf{1}$ with $\mathrm{O}_{2}$ was independent of the concentration of $\mathrm{O}_{2}$ (Figure $\mathrm{S} 7$ in SI), indicating that the mechanism of the reaction of $\mathbf{1}$ with $\mathrm{O}_{2}$ is the same as that of the NO-transfer reaction from 1 to $\left[\left(12-\mathrm{TMC} \mathrm{Co}^{\mathrm{II}}\right]^{2+}\right.$ (vide supra). There is an equilibrium between $\mathbf{1}$ and a cage molecule, $\{(14-\mathrm{TMC}) \mathrm{Co} \cdots \mathrm{NO}\}^{2+}$, prior to the reaction with $\mathrm{O}_{2}$, as shown in Scheme 4. Since the first step of the reaction (Scheme 4 , step $a$ ) is the rate-determining step, the overall rate constant $\left(k_{\mathrm{obs}}\right)$ of 7.6(7) $\times$ $10^{-4} \mathrm{~s}^{-1}$ is equal to the rate constant of the dissociation to the cage molecule because the rates of re-formation of $\mathbf{1}$ and reaction with $\mathrm{O}_{2}$ are much faster than that of the dissociation to the cage molecule. ${ }^{24}$

The products obtained in the reaction of $\mathbf{1}$ with $\mathrm{O}_{2}$ were analyzed by solution IR, ESI-MS, and EPR spectroscopies. Upon addition of $\mathrm{O}_{2}$ to a solution of $\mathbf{1}$, an IR peak at $1715 \mathrm{~cm}^{-1}$ for the NO stretching vibration of $\mathbf{1}$ disappeared, and concomitantly a new IR peak at 1302 
$\mathrm{cm}^{-1}$ due to a nitrate $\mathrm{NO}_{3}{ }^{-}$stretching vibration ${ }^{25}$ was formed (Figure $9 \mathrm{~b}$ ). ESI-MS spectrum of the reaction solution exhibited prominent mass peaks at $\mathrm{m} / z=377.1$ and 178.1 (Figure 9a, inset), whose mass and isotopic distribution patterns correspond to [(14-TMC)$\left.\mathrm{Co}^{\mathrm{II}}\left(\mathrm{NO}_{3}\right)\right]^{+}(6$, calcd $\mathrm{m} / z=377.1)$ and $\left[(14-\mathrm{TMC})-\mathrm{Co}^{\mathrm{II}}\left(\mathrm{CH}_{3} \mathrm{CN}\right)\right]^{2+}($ calcd $\mathrm{m} / z=178.1)$. When ${ }^{16} \mathrm{O}_{2}$ was replaced by isotopically labeled ${ }^{18} \mathrm{O}_{2}$, the mass peak at $\mathrm{m} / z=377.1$ was shifted to $\mathrm{m} / z=381.1$. (blue and red lines in Figure 9a, inset). The observed shift of four mass units indicates that two of the three $\mathrm{O}$ atms in the $\mathrm{NO}_{3}{ }^{-}$ligand of 6 are derived from $\mathrm{O}_{2}$. An EPR spectrum of the complete reaction solution exhibited signals at $g_{1}=7.0, g_{2}=$ 2.09 , and $g_{3}=1.52$, indicating that a high-spin cobalt(II) complex was the final product formed (Figure S8 in SI). ${ }^{26}$

Finally, $\mathbf{6}$ was structurally characterized using X-ray crystallography. Single crystals of $\mathbf{6}$ were grown from the solution obtained in the reaction of $\mathbf{1}$ with $\mathrm{O}_{2}$. The X-ray crystal structure of 6 revealed that the nitrate anion coordinates to Co center in a bidentate fashion to produce a product with pseudo-octahedral geometry (Figure 10). Co-O distances of 2.234 and $2.225 \AA$ indicate that two $\mathrm{O}$ atoms of the nitrate anion coordinate quite symmetrically to the Co center. The crystallographic data and selected bond distances and angles for $\mathbf{6}$ are listed in Tables S1-S3 in the SI.

According to the above results, we propose a reaction mechanism as shown in Scheme 4. The first step should be the dissociation of NO ligand from 1 to form a cage molecule, $\{(14-$ TMC)Co $\cdots \mathrm{NO}^{2+}$, indicating that the $\mathrm{Co}^{\mathrm{III}}$ center was reduced to $\mathrm{Co}^{\mathrm{II}}$. Then, this cage molecule, $\{(14-\mathrm{TMC}) \mathrm{Co} \cdots \mathrm{NO}\}^{2+}$, reacts with $\mathrm{O}_{2}$ to form a putative $\mathrm{Co}^{\mathrm{II}}$ peroxynitrite (PN) intermediate, $\mathrm{Co}^{\mathrm{II}}\left(\mathrm{OON}=\mathrm{O}^{-}\right)$(Scheme 4 , step $b$ ). Subsequently, isomerization of $\mathrm{Co}^{\mathrm{II}}-\mathrm{PN}$ would generate the $\mathrm{Co}^{\mathrm{II}}-\mathrm{NO}_{3}$ complex (6) (Scheme 4, step c), ${ }^{27}$ as reported previously in metal-bound PN intermediates. ${ }^{14,15,28}$ In the dioxygenation reaction of $\mathbf{1}$, we observed the formation of nitrate anion, which is the product formed by the isomerization of PN. ${ }^{14,15}$ Since metal-PNs are known to be extremely unstable, ${ }^{19}$ there are only few reports about the metal-bound PN complexes. ${ }^{29,30}$ However, $\mathrm{PN}$ is often proven to be present by its ability to effect phenol ring nitration. ${ }^{31}$ Thus, 2,4-di-tert-butylphenol (DTBP) was added to a solution of $\mathbf{1}$ prior to addition of dioxygen to support our proposed mechanism (Scheme 5). We found that 2,4-di-tert-butyl-6-nitrophenol (nitro-DTBP) and dimerized DTBP (2,2'-dihydroxy-3,3', 5,5'-tetra-tert-butylphenol) were produced with the yields of 60(5)\% and 10(4)\%, respectively (see Experimental Section). Thus, the experimental results, such as the formation of nitro-DTBP with a good yield, strongly support the proposed reaction mechanism, which is the formation of a Co-PN intermediate in the reaction of $\mathbf{1}$ with $\mathrm{O}_{2}$.

\section{CONCLUSION}

We have demonstrated for the first time that the NO-transfer and dioxygen reactivity of $\mathrm{Co}^{\mathrm{III}}$-nitrosyl complexes bearing $N$-tetramethylated cyclam ligands can be tuned by varying the ring size of the supporting ligands and/or the spin state of $\mathrm{Co}^{\mathrm{II}}$ ion. In the NO-transfer reaction and the reaction with $\mathrm{O}_{2}$, the reactivity of $\left[(14-\mathrm{TMC}) \mathrm{Co}^{\mathrm{III}}(\mathrm{NO})\right]^{2+}(\mathbf{1})$ was compared with that of a smaller ring-size congener, $\left[(12-\mathrm{TMC}) \mathrm{Co}^{\mathrm{III}}(\mathrm{NO})\right]^{2+}(\mathbf{2})$. We found that the NO moiety in $\mathbf{1}$ was transferred to $\left[(12-\mathrm{TMC}) \mathrm{Co}^{\mathrm{II}}\right]^{2+}$ to form $\mathbf{2}$, whereas no NOtransfer reaction occurred between 2 and $\left[(14-\mathrm{TMC}) \mathrm{Co}^{\mathrm{II}}\right]^{2+}$; these results were interpreted 
as being due to the higher NO binding affinity of $\left[(12-\mathrm{TMC}) \mathrm{Co}^{\mathrm{II}}\right]^{2+}$ compared to that of $\left[(14-\mathrm{TMC}) \mathrm{Co}^{\mathrm{II}}\right]^{2+}$. The NO-transfer reaction was independent of the $\left[(12-\mathrm{TMC}) \mathrm{Co}^{\mathrm{II}}\right]^{2+}$ concentration, leading us to suggest that the mechanism of the NO-transfer from 1 to [(12TMC)Co $\left.{ }^{\mathrm{II}}\right]^{2+}$ occurs via dissociation of the NO ligand from $\mathbf{1}$ to form a cage molecule, $\{(14-\mathrm{TMC}) \mathrm{Co} \cdots \mathrm{NO}\}^{2+}$, prior to its reaction with $\left[(12-\mathrm{TMC}) \mathrm{Co}^{\mathrm{II}}\right]^{2+}$ to produce 2 . DFT calculations supported the experimental observation for the NO dissociation pathway. In addition to the NO-transfer reaction, the reactivity of $\mathbf{1}$ toward $\mathrm{O}_{2}$ was investigated. A cobalt-nitrato complex, $\left[(14-\mathrm{TMC}) \mathrm{Co}^{\mathrm{II}}\left(\mathrm{NO}_{3}\right)\right]^{+}$, which was structurally characterized by $\mathrm{X}$ ray crystallography, was produced as a sole product in the reaction of $\mathbf{1}$ and $\mathrm{O}_{2}$, while $\mathbf{2}$ was inert toward $\mathrm{O}_{2} \cdot{ }^{22}$ The reaction rate of $\mathbf{1}$ with $\mathrm{O}_{2}$ was independent of the $\mathrm{O}_{2}$ concentration, indicating that the reaction mechanism of $\mathbf{1}$ and $\mathrm{O}_{2}$ is similar to that of the NO-transfer reaction from $\mathbf{1}$ to $\left[(12-\mathrm{TMC}) \mathrm{Co}^{\mathrm{II}}\right]^{2+}$, which occurs via a dissociation of NO ligand from $\mathbf{1}$ to form a cage molecule, $\{(14-\mathrm{TMC}) \mathrm{Co} \cdots \mathrm{NO}\}^{2+}$, prior to the reaction with $\mathrm{O}_{2}$. The reaction of the cage molecule, $\{(14-\mathrm{TMC}) \mathrm{Co} \cdots \mathrm{NO}\}^{2+}$, with $\mathrm{O}_{2}$ produces a putative peroxynitrite $(\mathrm{PN})$ intermediate, $\mathrm{Co}{ }^{\mathrm{II}}\left(\mathrm{OON}=\mathrm{O}^{-}\right)$, which is converted to the final $\mathrm{Co}^{\mathrm{II}}-\mathrm{NO}_{3}$ product. As a conclusion, we have demonstrated unambiguously that the reactivities of the cobalt(III)nitrosyl complexes bearing TMC ligands in the NO-transfer and dioxygenation reactions are significantly influenced by the spin state of the cobalt(II) center, caused by the ring size of the TMC ligands. Such explanations have also been provided and published for other firstrow transition metal ions, where the chemistries are compared using metal complexes bearing different ring-size TMC ligands. ${ }^{32}$

\section{EXPERIMENTAL SECTION}

\section{Materials}

All chemicals obtained from Aldrich Chemical Co. were of the best available purity and used without further purification unless otherwise indicated. Solvents were dried according to published procedures and distilled under Ar prior to use. ${ }^{33}$ The 14-TMC ligand and 1,4,7,10-tetraazacyclododecane compound were purchased from Aldrich Chemical Co. 12TMC was prepared by reacting excess amounts of formaldehyde and formic acid with 1,4,7,10-tetraazacyclododecane. ${ }^{34}\left[(14-\mathrm{TMC}) \mathrm{Co}^{\mathrm{II}}\right]^{2+}$ and $\left[(12-\mathrm{TMC}) \mathrm{Co}^{\mathrm{II}}\right]^{2+}$ complexes were synthesized and isolated according to the literature methods. ${ }^{21 \mathrm{~b}} \mathrm{Co}(\mathrm{III})-$ nitrosyl complexes (1 and $\mathbf{2}$ ) were synthesized by reported procedures. ${ }^{22}$

\section{Instrumentation}

UV-vis spectra were recorded on a Hewlett-Packard 8453 diode array spectrometer equipped with a UNISOKU Scientific Instruments for low-temperature experiments. Coldspray ionization time-of-flight mass (CSI-TOF MS) spectral data were collected on a JMS-T100CS (JEOL) mass spectrometer equipped with the CSI source. Typical measurement conditions are as follows: needle voltage, $2.2 \mathrm{kV}$; orifice 1 current, 50-500 nA; orifice 1 voltage, $0-20 \mathrm{~V}$; ring lens voltage, $10 \mathrm{~V}$; ion source temperature, $5^{\circ} \mathrm{C}$; spray temperature, $-40^{\circ} \mathrm{C}$. Electrospray ionization mass spectra (ESI-MS) were collected on a Thermo Finnigan (San Jose, CA, USA) LCQTM Advantage MAX quadrupole ion trap instrument, by infusing samples directly into the source using a manual method. The spray voltage was set at $4.2 \mathrm{kV}$ and the capillary temperature at $80^{\circ} \mathrm{C}$. EPR spectra were recorded 
at $5 \mathrm{~K}$ using an X-band Bruker EMX-plus spectrometer equipped with a dual-mode cavity (ER 4116DM). Low temperatures were achieved and controlled using an Oxford Instruments ESR900 liquid He quartz cryostat with an Oxford Instruments ITC503 temperature and gas flow controller. Low-temperature solution IR spectra were recorded on Remspec 626 FT-IR spectrometer. ${ }^{1} \mathrm{H}$ NMR spectra were measured with a Bruker model digital AVANCE III 400 FT-NMR spectrometer. Crystallographic data collections were carried out on a Bruker SMART AXS diffractometer equipped with a monochromator in the Mo $\mathrm{K} a(\lambda=0.71073 \AA)$ incident beam.

\section{Purification of Nitric Oxide}

Nitric oxide gas $\left(\mathrm{NO}_{(\mathrm{g})}\right)$ was purchased from Dong-A Specialty Gases in Korea and purified as follows: ${ }^{22} \mathrm{NO}_{(\mathrm{g})}$ was first passed through two columns filled with $\mathrm{NaOH}$ beads and molecular sieves to remove higher nitrogen oxide and moisture impurities and collected in a frozen form in a first trap cooled at $77 \mathrm{~K}$ with liquid $\mathrm{N}_{2}$. Further purification was done by distillation of frozen $\mathrm{NO}_{(\mathrm{g})}$ (as crystalline $\mathrm{N}_{2} \mathrm{O}_{2}$ ) by warming at $-80{ }^{\circ} \mathrm{C}$ (acetone/dry ice mixture, $-80{ }^{\circ} \mathrm{C}$ ), collecting it in a second trap cooled at $77 \mathrm{~K}$ with liquid $\mathrm{N}_{2}$. This second trap was again warmed to $-80{ }^{\circ} \mathrm{C}$, and the highly purified $\mathrm{NO}_{(\mathrm{g})}$ was collected in another vacuumed Schlenk flask fitted with a rubber septum (free from oxygen, after several cycles of vacuum and Ar purging). The $\mathrm{NO}_{(\mathrm{g})}$ should be at high pressure in the Schlenk flash (>1 atm; the septum bulges outward due to high pressures inside the Schlenk flask). Then, $\mathrm{NO}_{(\mathrm{g})}$ was purged to the distilled and degassed $\mathrm{CH}_{3} \mathrm{CN}(15 \mathrm{~mL})$ in a Schlenk flask, which was already connected with an oil bubbler. $\mathrm{NO}_{(\mathrm{g})}$ purging with vigorous stirring under $1 \mathrm{~atm}$ for 20 min is required to make NO-saturated $\mathrm{CH}_{3} \mathrm{CN}$ solution. The concentration of NOsaturated in $\mathrm{CH}_{3} \mathrm{CN}$ solution at $20{ }^{\circ} \mathrm{C}$ was approximated to be $14 \mathrm{mM}$ based on published values for $\mathrm{NO}_{(\mathrm{g})}$ solubility. ${ }^{35}$ According to the literature, $\mathrm{NO}_{(\mathrm{g})}$ solubility in diethyl ether is $27 \mathrm{mM}$, while for most other non-ethereal organic solvents the values are in the range of 11$18 \mathrm{mM} \cdot{ }^{35}$

\section{X-ray Crystallography}

The single crystals of $6-\left(\mathrm{BPh}_{4}\right)$, which were formed by anion exchange with $\mathrm{BPh}_{4}{ }^{-}$from 6 $\left(\mathrm{ClO}_{4}\right)$ complex, were obtained by slow diffusion of $\mathrm{Et}_{2} \mathrm{O}$ into the $\mathrm{CH}_{3} \mathrm{CN}$ solution at $-30{ }^{\circ} \mathrm{C}$. We tried to grow the suitable crystals of $6-\left(\mathrm{ClO}_{4}\right)$, but we failed to grow them because of high degree of disorder in perchlorate anion. Thus, to grow suitable crystals, $\mathrm{ClO}_{4}$ anion was exchanged to $\mathrm{BPh}_{4}$ anion. A single crystal of $6-\left(\mathrm{BPh}_{4}\right)$ was picked from solution by a nylon loop (Hampton Research Co.) and mounted on a goniometer head in a $\mathrm{N}_{2(\mathrm{~g})}$ cryostream. Data collections were carried out on a Bruker SMART AXS diffractometer equipped with a monochromator in the $\operatorname{Mo} K a(\lambda=0.71073 \AA)$ incident beam. The $\mathrm{CCD}$ data for $\mathbf{6}-\left(\mathrm{BPh}_{4}\right)$ were integrated and scaled using the Bruker-SAINT software package, and the structure was solved and refined using SHELXTL V 6.12.25. ${ }^{36}$ The crystallographic data and selected bond distances and angles for $\mathbf{6}-\left(\mathrm{BPh}_{4}\right)$ are listed in Tables S1-S3 in the SI. CCDC-1449724 for 6-( $\left.\mathrm{BPh}_{4}\right)$ contains the supplementary crystallographic data for this paper. These data can be obtained free of charge via www.ccdc.cam.ac.uk/data_request/cif (or from the Cambridge Crystallographic Data Centre, 12 Union Rd., Cambridge CB2 1EZ, UK; fax (+44) 1223-336-033, or deposit@ccdc.cam.ac.uk). 


\section{Reactivity Studies}

All the reactions were run in a $1 \mathrm{~cm} \mathrm{UV}$ cuvette, by monitoring the UV-vis spectral changes of the reaction solutions, and the rate constants were determined by fitting the changes in absorbance at 393 and $368 \mathrm{~nm}$ for $\mathbf{1}$ and $\mathbf{2}$, respectively. Reactions were run at least in triplicate, and the data reported represent the average of these reactions. Complex $\mathbf{1}$ was prepared in situ by reaction of $\left[(14-\mathrm{TMC}) \mathrm{Co}^{\mathrm{II}}\right]^{2+}$ with an equal amount of $\mathrm{NO}_{(\mathrm{g})}$ under an Ar atmosphere in $\mathrm{CH}_{3} \mathrm{CN}$ at $-40{ }^{\circ} \mathrm{C} .1(0.50 \mathrm{mM})$ was then used in different reactivity studies, such as NO-transfer and $\mathrm{NO}$ dioxygenation reactions under above reaction conditions. The NO-transfer reactions were carried out by adding different amounts of [(12TMC)Co $\left.{ }^{\mathrm{II}}\right]^{2+}(0.50,2.5$, and $5.0 \mathrm{mM})$ to a solution of $\mathbf{1}(0.50 \mathrm{mM})$, which was in situ prepared under an $\mathrm{Ar}$ atmosphere in $\mathrm{CH}_{3} \mathrm{CN}$ at $-40{ }^{\circ} \mathrm{C}$. UV-vis spectral changes were monitored at $368 \mathrm{~nm}$ due to $\mathbf{2}$, and rate constants were determined by fitting the changes in absorbance at $368 \mathrm{~nm}$. In NO-transfer reactions, the yields were measured by comparing molar extinction coefficient $(\varepsilon)$ of $\mathbf{2}$ at $368 \mathrm{~nm}$ with authentic sample. ${ }^{22}$ The reactions of $\mathbf{1}$ with $\mathrm{O}_{2}$ were carried out by purging excess $\mathrm{O}_{2}(0.10 \mathrm{M})$ to a $\mathrm{CH}_{3} \mathrm{CN}$ solution of $\mathbf{1}(0.50$ $\mathrm{mM})$ at $-40{ }^{\circ} \mathrm{C}$. The reactions were followed by monitoring the change in absorbance at 395 $\mathrm{nm}$.

Reaction of 1 with 2,4-di-tert-butylphenol (DTBP) were carried out in $\mathrm{CH}_{3} \mathrm{CN}$ at $-40{ }^{\circ} \mathrm{C} .1$ $\left(2.0 \mathrm{mM}, 5.0 \mathrm{~mL}\right.$ ) was prepared under an $\mathrm{Ar}$ atmosphere in $\mathrm{CH}_{3} \mathrm{CN}$ at $-40{ }^{\circ} \mathrm{C}$ in a $30 \mathrm{~mL}$ Schlenk flask fitted with a septum. Upon addition of DTBP to a solution of $\mathbf{1}$, no reaction occurred. However, upon addition of excess oxygen to a solution containing $\mathbf{1}$ and DTBP in $\mathrm{CH}_{3} \mathrm{CN}$ at $-40{ }^{\circ} \mathrm{C}$, the absorption band at $395 \mathrm{~nm}$ due to 1 disappeared. The reaction mixture was stirred for $3 \mathrm{~h}$ at $-40{ }^{\circ} \mathrm{C}$ before warming to room temperature. The products were analyzed by injecting reaction mixture directly into a GC and were identified by comparison with authentic samples. The product yields were determined to be 60(5)\% for 2,4-di-tert-butyl-6-nitrophenol and 10(4)\% for 2,2'-dihydroxy-3,3',5,5'-tetra-tertbutylbiphenol by comparison against standard curves prepared with authentic samples and using decane as an internal standard.

\section{EPR Spectroscopy}

EPR spectra were recorded for different reactions, such as generation of 1, NO-transfer reaction from $\mathbf{1}$ to $\left[(12-\mathrm{TMC}) \mathrm{Co}^{\mathrm{II}}\right]^{2+}$, and dioxygenation reaction of $\mathbf{1}$. All the reactions were performed under an $\mathrm{Ar}$ atmosphere in $\mathrm{CH}_{3} \mathrm{CN}$ at $-40{ }^{\circ} \mathrm{C}$, and then EPR spectra were recorded at $5 \mathrm{~K}$. In the case of NO-transfer reaction, EPR spectral changes as a function of time $(0-170 \mathrm{~min})$ have been recorded at $5 \mathrm{~K}$ for the reaction of $\mathbf{1}(2.0 \mathrm{mM})$ with equivalent amount of $\left[(12-\mathrm{TMC}) \mathrm{Co}^{\mathrm{II}}\right]^{2+}$ in $\mathrm{CH}_{3} \mathrm{CN}$ at $-40{ }^{\circ} \mathrm{C}$. Time-dependent EPR measurements revealed the clear conversion of $\mathbf{1}$ to 2 .

\section{Solution IR Spectroscopy}

Solution IR spectra for samples were recorded with a sophisticated setup, attached to an IR instrument (Remspec model 626) equipped with a very sensitive probe under an $\mathrm{Ar}$ atmosphere in $\mathrm{CH}_{3} \mathrm{CN}$ at $-40{ }^{\circ} \mathrm{C}$. The formation of $\mathrm{Co}$ (III)-nitrosyl complexes ( $\mathbf{1}$ and $\mathbf{2}$ ), NO-transfer reactions, and dioxygenation reactivity of $\mathbf{1}$ were followed by monitoring the 
characteristic nitrosyl stretching vibration bands. $1(3.0 \mathrm{mM}, 2.0 \mathrm{~mL})$ was in situ prepared under the above experimental conditions/setup and showed the formation of a peak at 1715 $\mathrm{cm}^{-1}$, which corresponds to nitrosyl stretching in solution medium. Solution IR spectral changes for the reaction of $\mathbf{1}(3.0 \mathrm{mM}, 2.0 \mathrm{~mL})$ with equal amount of $\left[(12-\mathrm{TMC}) \mathrm{Co}^{\mathrm{II}}\right]^{2+}$ show the shifting of characteristic nitrosyl stretching of $\mathbf{1}\left(1715 \mathrm{~cm}^{-1}\right)$ to $1712 \mathrm{~cm}^{-1}$ (corresponding to 2). In addition, solution IR spectral changes for reaction of $\mathbf{1}$ ( $3.0 \mathrm{mM}, 2.0$ $\mathrm{mL}$ ) with dioxygen were also recorded in $\mathrm{CH}_{3} \mathrm{CN}$ at $-40{ }^{\circ} \mathrm{C}$, showing that the decay of the peak at $1715 \mathrm{~cm}^{-1}$ due to $\mathbf{1}$, and concomitantly the formation of a new peak at $1302 \mathrm{~cm}^{-1}$, which corresponds to a $\mathrm{NO}_{3}{ }^{-}$stretching vibration, ${ }^{25}$ was observed.

\section{Synthesis of $\left[(14-\mathrm{TMC}) \mathrm{Co}^{\mathrm{Il}}\left(\mathrm{NO}_{3}\right)\right]\left(\mathrm{BPh}_{4}\right)$}

Upon addition of an aqueous solution of sodium tetraphenylborate (52 $\mathrm{mg}, 0.15 \mathrm{mmol}$ ) to a $\mathrm{CH}_{3} \mathrm{OH}$ solution of $\left[(14-\mathrm{TMC}) \mathrm{Co}^{\mathrm{II}}\right]^{2+}(56 \mathrm{mg}, 0.1 \mathrm{mmol})$ at room temperature, a very lightcolored precipitate of $\left[(14-\mathrm{TMC}) \mathrm{Co}^{\mathrm{II}}\right]-\left(\mathrm{BPh}_{4}\right)_{2}$ was produced within $10 \mathrm{~min}$. The precipitate was filtered, washed with cold methanol, and then dried over $\mathrm{CaCl}_{2}$ under vacuum. [(14$\left.\mathrm{TMC}) \mathrm{Co}^{\mathrm{III}}(\mathrm{NO})\right]^{+}$was also generated by reacting $\left[(14-\mathrm{TMC})-\mathrm{Co}^{\mathrm{II}}\right]\left(\mathrm{BPh}_{4}\right)_{2}(3.0 \mathrm{mM}, 10$ $\mathrm{mL}$ ) with an equal amount of $\mathrm{NO}$, and then $\left[(14-\mathrm{TMC}) \mathrm{Co}^{\mathrm{II}}\left(\mathrm{NO}_{3}\right)\right]\left(\mathrm{BPh}_{4}\right)$ was obtained by reacting with excess dioxygen in $\mathrm{CH}_{3} \mathrm{CN}$ at $-40{ }^{\circ} \mathrm{C}$ over $3 \mathrm{~h}$. The reaction mixture containing [(14-TMC) $\left.\mathrm{Co}^{\mathrm{II}}\left(\mathrm{NO}_{3}\right)\right]\left(\mathrm{BPh}_{4}\right)$ was layered with Ar-saturated $\mathrm{Et}_{2} \mathrm{O}$ for several days at $-30{ }^{\circ} \mathrm{C}$ to obtain the light pink-colored crystals of $\mathbf{6}-\left(\mathrm{BPh}_{4}\right)$.

\section{Supplementary Material}

Refer to Web version on PubMed Central for supplementary material.

\section{ACKNOWLEDGMENTS}

The authors gratefully acknowledge financial support from the NRF of Korea through CRI

(NRF-2012R1A3A2048842 to W.N.) and GRL (NRF-2010-00353 to W.N.) along with the U.S. National Institutes of Health (to K.D.K.), the National Natural Science Foundation of China (21290194, 21521062, and 21473215 to H.C.), and the Ministry of Science and Technology of China (2012YQ120060 to J.Y.).

\section{REFERENCES}

(1). (a) Furchgott RF. Angew. Chem., Int. Ed. 1999; 38:1870.(b) Ignarro LJ. Angew. Chem., Int. Ed. 1999; 38:1882.(c) Murad F. Angew. Chem., Int. Ed. 1999; 38:1856.(d) Ignarro, LJ. Nitric Oxide, Biology and Pathobiology. Academic Press; San Diego, CA: 2000. (e) Richter-Addo GB, Legzdins P, Burstyn J. Chem. Rev. 2002; 102:857. [PubMed: 11942780] (f) Wasser IM, de Vries S, Moënne-Loccoz P, Schröder I, Karlin KD. Chem. Rev. 2002; 102:1201. [PubMed: 11942794] (g) Møller JKS, Skibsted LH. Chem. Rev. 2002; 102:1167. [PubMed: 11942791] (h) Bon CLM, Garthwaite J. J. Neurosci. 2003; 23:1941. [PubMed: 12629199] (i) Pepicelli O, Raiteri M, Fedele E. Neurochem. Int. 2004; 45:787. [PubMed: 15312973]

(2). (a) Martin CT, Morse RH, Kanne RM, Gray HB, Malmström BG, Chan SI. Biochemistry. 1981; 20:5147. [PubMed: 6271178] (b) Cooper CE, Torres J, Sharpe MA, Wilson MT. FEBS Lett. 1997; 414:281. [PubMed: 9315702] (c) Tocheva EI, Rosell FI, Mauk AG, Murphy MEP. Science. 2004; 304:867. [PubMed: 15131305] (d) Lehnert, N.; Berto, TC.; Galinato, MGI.; Goodrich, LE. The Handbook of Porphyrin Science. Kadish, KM.; Smith, K.; Guilard, R., editors. World Scientific; Hackensack, NJ: 2011. p. 1-247.

(3). (a) Enemark JH, Feltham RD. Coord. Chem. Rev. 1974; 13:339.(b) Richter-Addo, GB.; Legzdins, P. Metal Nitrosyls. Oxford University Press; New York: 1992. (c) McCleverty JA. Chem. Rev. 
2004; 104:403. [PubMed: 14871130] (d) Ford PC, Lorkovic IM. Chem. Rev. 2002; 102:993. [PubMed: 11942785] (e) Heinecke J, Ford PC. Coord. Chem. Rev. 2010; 254:235.(f) Fry NL, Mascharak PK. Acc. Chem. Res. 2011; 44:289. [PubMed: 21361269] (g) Berto TC, Speelman AL, Zheng S, Lehnert N. Coord. Chem. Rev. 2013; 257:244.(h) Tsai M-L, Tsou C-C, Liaw W-F. Acc. Chem. Res. 2015; 48:1184. [PubMed: 25837426] (i) Pulukkody R, Darensbourg M. Acc. Chem. Res. 2015; 48:2049. [PubMed: 26090911] (j) Hunt AP, Lehnert N. Acc. Chem. Res. 2015; 48:2117. [PubMed: 26114618] (k) Fitzpatrick J, Kim E. Acc. Chem. Res. 2015; 48:2453. [PubMed: 26197209] (l) Hematian S, Garcia-Bosch I, Karlin KD. Acc. Chem. Res. 2015; 48:2462. [PubMed: 26244814]

(4). (a) Cho J, Sarangi R, Annaraj J, Kim SY, Kubo M, Ogura T, Solomon EI, Nam W. Nat. Chem. 2009; 1:568. [PubMed: 20711413] (b) Sastri CV, Oh K, Lee YJ, Seo MS, Shin W, Nam W. Angew. Chem., Int. Ed. 2006; 45:3992.

(5). (a) Armor J. Inorg. Chem. 1973; 12:1959.(b) Roberts RL, Carlyle DW, Blackmer GL. Inorg. Chem. 1975; 14:2739.(c) Ungermann CB, Caulton KG. J. Am. Chem. Soc. 1976; 98:3862.

(6). Doyle MP, Pickering RA, Dykstra RL, Cook BR. J. Am. Chem. Soc. 1982; 104:3392.

(7). Franz KJ, Lippard SJ. Inorg. Chem. 2000; 39:3722. [PubMed: 11196841]

(8). Metzker G, Lopes PP, da Silva ACH, da Silva SC, Franco DW. Inorg. Chem. 2014; 53:4475. [PubMed: 24738470]

(9). (a) Clarkson SG, Basolo F. J. Chem. Soc., Chem. Commun. 1972:670.(b) Clarkson SG, Basolo F. Inorg. Chem. 1973; 12:1528.

(10). (a) Cheng L, Powell DR, Khan MA, Richter-Addo GB. Chem. Commun. 2000:2301.(b) Videla M, Roncaroli F, Slep LD, Olabe JA. J. Am. Chem. Soc. 2007; 129:278. [PubMed: 17212399] (c) Roncaroli F, Videla M, Slep LD, Olabe JA. Coord. Chem. Rev. 2007; 251:1903.(d) Subedi H, Brasch NE. Inorg. Chem. 2013; 52:11608. [PubMed: 24050193]

(11). Skodje KM, Williard PG, Kim E. Dalton Trans. 2012; 41:7849. [PubMed: 22538296]

(12). (a) Blough NV, Zafiriou OC. Inorg. Chem. 1985; 24:3502.(b) Nauser T, Koppenol WH. J. Phys. Chem. A. 2002; 106:4084.

(13). (a) Pfeiffer S, Gorren ACF, Schmidt K, Werner ER, Hansert B, Bohle DS, Mayer B. J. Biol. Chem. 1997; 272:3465. [PubMed: 9013592] (b) Coddington JW, Hurst JK, Lymar SV. J. Am. Chem. Soc. 1999; 121:2438.(c) Lymar SV, Khairutdinov RF, Hurst JK. Inorg. Chem. 2003; 42:5259. [PubMed: 12924897] (d) Goldstein S, Lind J, Merényi G. Chem. Rev. 2005; 105:2457. [PubMed: 15941219] (e) Koppenol WH, Bounds PL, Nauser T, Kissner R, Rüegger H. Dalton Trans. 2012; 41:13779. [PubMed: 23007920] (f) Molina C, Kissner R, Koppenol WH. Dalton Trans. 2013; 42:9898. [PubMed: 23698514]

(14). (a) Schopfer MP, Wang J, Karlin KD. Inorg. Chem. 2010; 49:6267. [PubMed: 20666386] (b) Ouellet H, Ouellet Y, Richard C, Labarre M, Wittenberg B, Wittenberg J, Guertin M. Proc. Natl. Acad. Sci. U. S. A. 2002; 99:5902. [PubMed: 11959913]

(15). (a) Gardner PR, Gardner AM, Martin LA, Salzman AL. Proc. Natl. Acad. Sci. U. S. A. 1998; 95:10378. [PubMed: 9724711] (b) Ford PC, Lorkovic IM. Chem. Rev. 2002; 102:993. [PubMed: 11942785] (c) Gardner PR, Gardner AM, Brashear WT, Suzuki T, Hvitved AN, Setchell KDR, Olson JS. J. Inorg. Biochem. 2006; 100:542. [PubMed: 16439024]

(16). (a) Pestovsky O, Bakac A. J. Am. Chem. Soc. 2002; 124:1698. [PubMed: 11853446] (b) Herold S, Koppenol WH. Coord. Chem. Rev. 2005; 249:499.(c) Su J, Groves JT. Inorg. Chem. 2010; 49:6317. [PubMed: 20666389]

(17). (a) Yokoyama A, Han JE, Cho J, Kubo M, Ogura T, Siegler MA, Karlin KD, Nam W. J. Am. Chem. Soc. 2012; 134:15269. [PubMed: 22950528] (b) Yokoyama A, Cho K-B, Karlin KD, Nam W. J. Am. Chem. Soc. 2013; 135:14900. [PubMed: 24066924] (c) Yokoyama A, Han JE, Karlin KD, Nam W. Chem. Commun. 2014; 50:1742.

(18). (a) Maiti D, Lee D-H, Sarjeant AAN, Pau MYM, Solomon EI, Gaoutchenova K, Sundermeyer J, Karlin KD. J. Am. Chem. Soc. 2008; 130:6700. [PubMed: 18457392] (b) Park GY, Deepalatha S, Puiu SC, Lee D-H, Mondal B, Narducci Sarjeant AA, del Rio D, Pau MYM, Solomon EI, Karlin KD. J. Biol. Inorg. Chem. 2009; 14:1301-1311. [PubMed: 19662443]

(19). Kurtikyan TS, Ford PC. Chem. Commun. 2010; 46:8570. 
(20). (a) Kurtikyan TS, Eksuzyan SR, Hayrapetyan VA, Martirosyan GG, Hovhannisyan GS, Goodwin JA. J. Am. Chem. Soc. 2012; 134:13861. [PubMed: 22881578] (b) Kurtikyan TS, Eksuzyan SR, Goodwin JA, Hovhannisyan GS. Inorg. Chem. 2013; 52:12046. [PubMed: 24090349]

(21). (a) Nam W. Acc. Chem. Res. 2015; 48:2415. [PubMed: 26203519] (b) Cho J, Jeon S, Wilson SA, Liu LV, Kang EA, Braymer JJ, Lim MH, Hedman B, Hodgson KO, Valentine JS, Solomon EI, Nam W. Nature. 2011; 478:502. [PubMed: 22031443]

(22). Kumar P, Lee Y-M, Park YJ, Siegler MA, Karlin KD, Nam W. J. Am. Chem. Soc. 2015; 137:4284. [PubMed: 25793706]

(23). The stability of $\mathbf{1}$ in the absence of substrate (i.e., $\left[(12-\mathrm{TMC}) \mathrm{Co}^{\mathrm{II}}\right]^{2+}$ ) in $\mathrm{CH}_{3} \mathrm{CN}$ indicates that the NO-dissociation and NO-transfer reaction could not be a solvent-assisted process (Figure 3a, inset).

(24). (a) Solc M. Nature. 1966; 209:706.(b) Holleman, AF.; Wiberg, E. Inorganic Chemistry. Academic Press; San Diego: 2001.

(25). Nakamoto, K. Infrared and Raman Spectra of Inorganic and Coordination Compounds, Part B, Applications in Coordination, Organometallic, and Bioinorganic Chemistry. 6th ed.. John Wiley \& Sons, Inc.; Hoboken, NJ: 2009.

(26). The final product obtained is a $\mathrm{Co}$ (II) complex, not a $\mathrm{Co}$ (III) complex, indicating that there is a missing electron in the overall reaction of $\mathbf{1}$ with $\mathrm{O}_{2}$ to give $\mathrm{Co}(\mathrm{II})$-nitrato complex $\mathbf{6}$, which was confirmed by X-ray crystallography, ESI-MS, and EPR spectroscopy. That is the reason why we did not describe a more detailed mechanism and, based only on the product analyses, we proposed the reaction mechanism of 1 with $\mathrm{O}_{2}$ (see Scheme 4).

(27). The peroxynitrite isomerization to nitrate is generally thought to occur extremely rapidly, sometimes without observable intermediates. It can occur by an initial homolytic cleavage of the $\mathrm{PN} \mathrm{O}-\mathrm{O}$ bond, forming a high-valent metal-oxo and nitrogen dioxide $\left(\mathrm{NO}_{2}\right)$ molecule within a cage, followed by re-formation of an $\mathrm{N}-\mathrm{O}$ bond to give nitrate.

(28). (a) Owen TM, Rohde J-U. Inorg. Chem. 2011; 50:5283. [PubMed: 21526756] (b) Ford PC, Fernandez BO, Lim MD. Chem. Rev. 2005; 105:2439. [PubMed: 15941218]

(29). Wick PK, Kissner R, Koppenol WH. Helv. Chim. Acta. 2000; 83:748.

(30). Tran NG, Kalyvas H, Skodje KM, Hayashi T, Moënne-Loccoz P, Callan PE, Shearer J, Kirschenbaum LJ, Kim E. J. Am. Chem. Soc. 2011; 133:1184. [PubMed: 21244001]

(31). (a) Gunaydin H, Houk KN. Chem. Res. Toxicol. 2009; 22:894. [PubMed: 19374346] (b) FerrerSueta G, Radi R. ACS Chem. Biol. 2009; 4:161. [PubMed: 19267456]

(32). (a) Cho J, Sarangi R, Nam W. Acc. Chem. Res. 2012; 45:1321. [PubMed: 22612523] (b) GarciaBosch I, Cowley RE, Díaz DE, Siegler MA, Nam W, Solomon EI, Karlin KD. Chem. -Eur. J. 2016; 22:5133. [PubMed: 26919169]

(33). Armarego, WLF; Chai, CLL. Purification of Laboratory Chemicals. 6th ed.. Pergamon Press; Oxford, U.K.: 2009.

(34). Halfen JA, Young VG Jr. Chem. Commun. 2003:2894.

(35). Young, CL. Solubility Data Series Vol. 8: Oxides of Nitrogen. International Union of Pure and Applied Chemistry (IUPAC); 1981.

(36). Sheldick, GM. SHELXTL/PC, Version 6.12 for Windows XP. Bruker Axs Inc.; Madison, WI: 2001. 


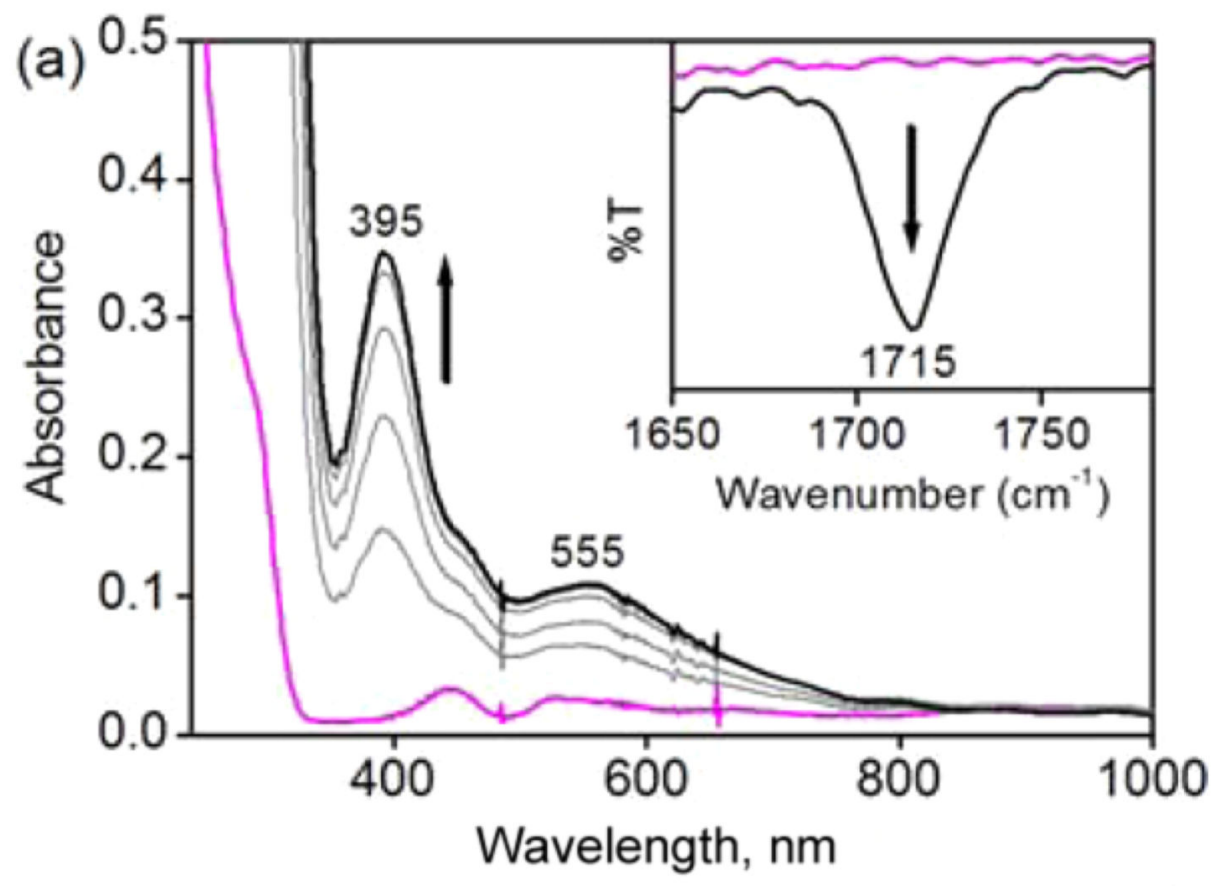

(b)

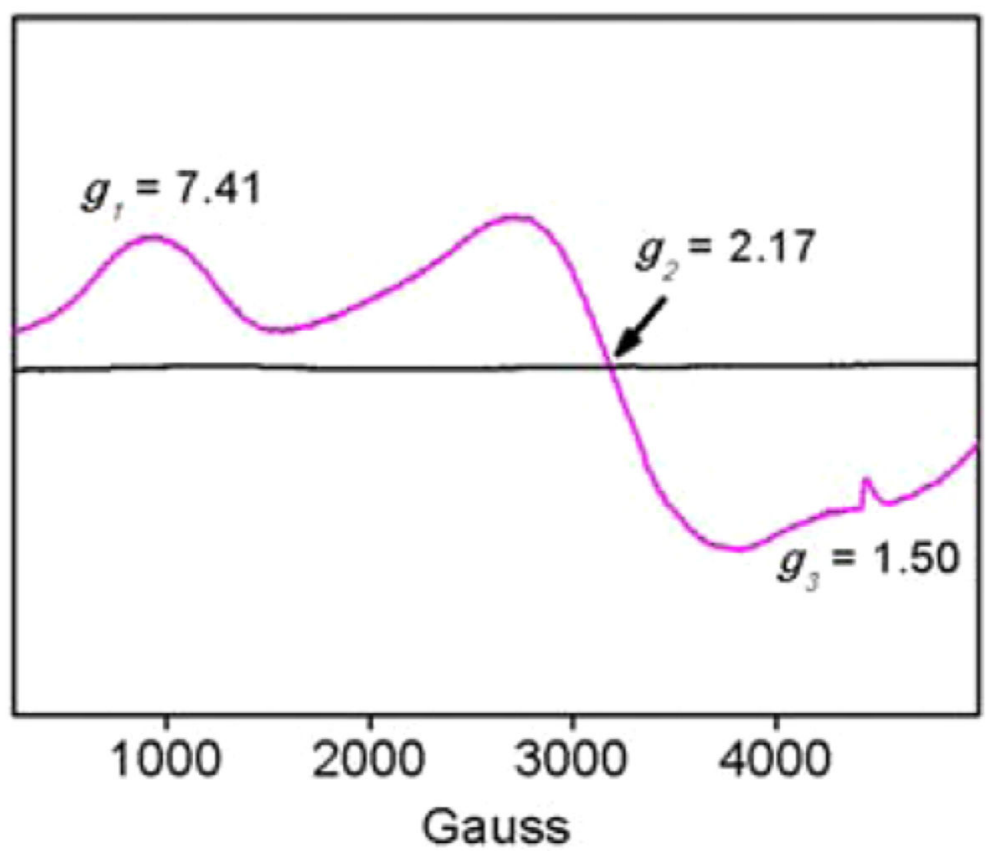

Figure 1.

(a) UV-vis spectral changes for the formation of 1 upon addition of $\mathrm{NO}$ ( 1 equiv) to a solution of $\left[(14-\mathrm{TMC}) \mathrm{Co}^{\mathrm{II}}\right]^{2+}$ (pink line; $0.50 \mathrm{mM}$ ) under an $\mathrm{Ar}$ atmosphere in $\mathrm{CH}_{3} \mathrm{CN}$ at $-40{ }^{\circ} \mathrm{C}$. 1 was generated within $3 \mathrm{~min}$. Inset: Solution IR spectra of $\mathbf{1}$ (3.0 mM, black line) and $\left[(14-\mathrm{TMC}) \mathrm{Co}^{\mathrm{II}}\right]^{2+}\left(3.0 \mathrm{mM}\right.$, pink line) recorded under an $\mathrm{Ar}$ atmosphere in $\mathrm{CH}_{3} \mathrm{CN}$ at $-40{ }^{\circ} \mathrm{C}$. (b) EPR spectra of 1 (black line) and [(14-TMC)Co $\left.{ }^{\mathrm{II}}\right]^{2+}$ (pink line) recorded in $\mathrm{CH}_{3} \mathrm{CN}$ at $5 \mathrm{~K}$. 
(a)

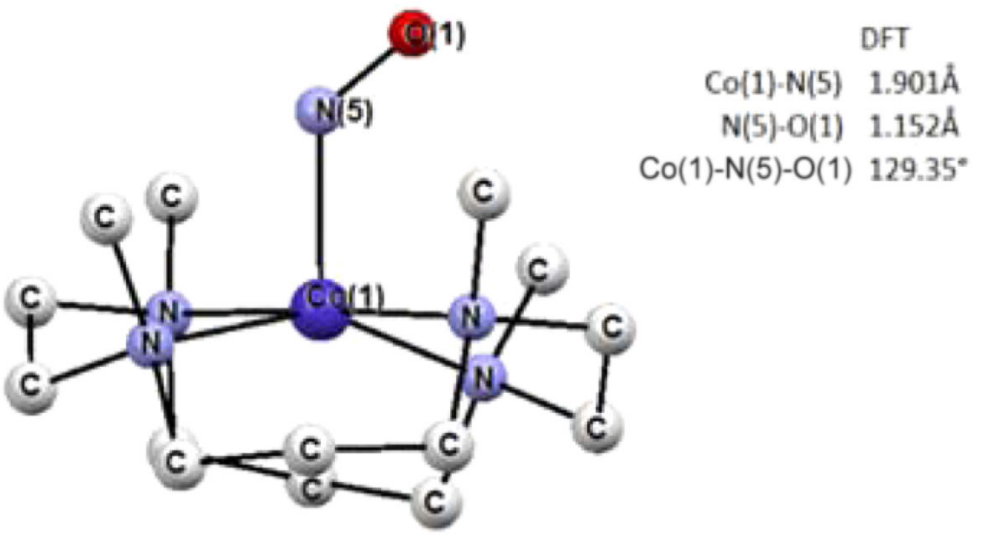

(b)

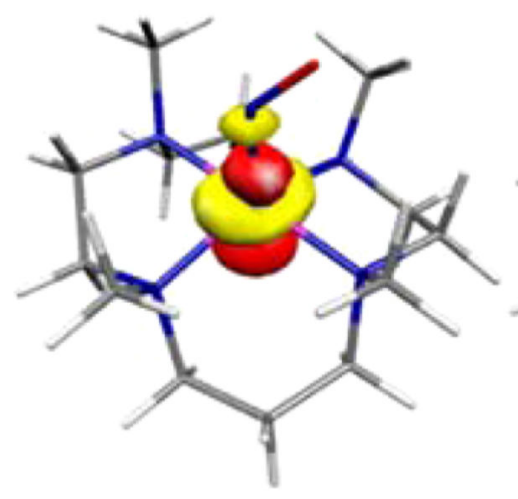

$d_{z^{2}}$

(c)

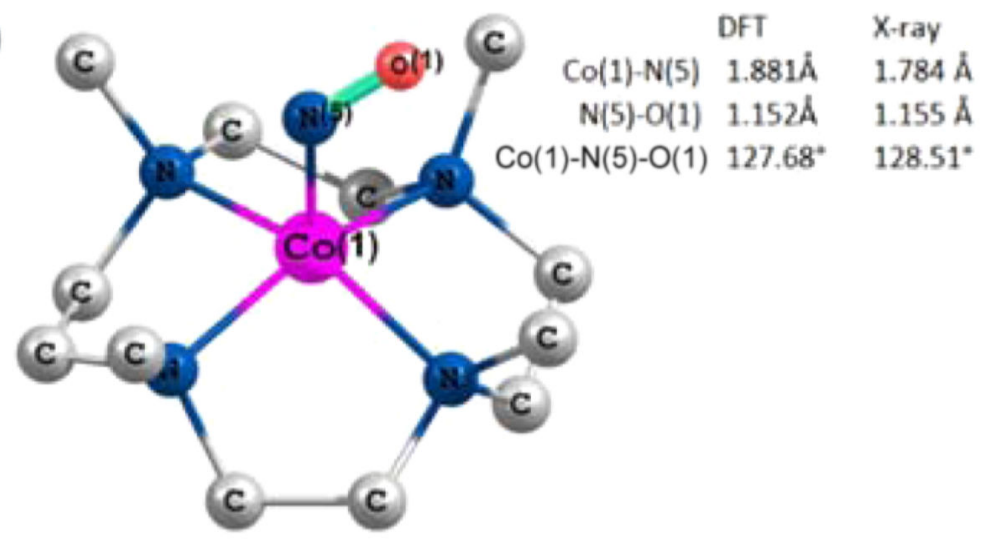

Figure 2.

(a) DFT-optimized geometry of [(14-TMC)Co $\left.{ }^{\mathrm{III}}(\mathrm{NO})\right]^{2+}(\mathbf{1})$ in the singlet ground state. (b) The two singly occupied orbitals accormodating two electrons with opposite spins in the singlet ground state of $\mathbf{1}$. (c) DFT-optimized geometry of the singlet ground state of 2 compared with the corresponding X-ray crystal structure. H-atoms are omitted for clarity. 

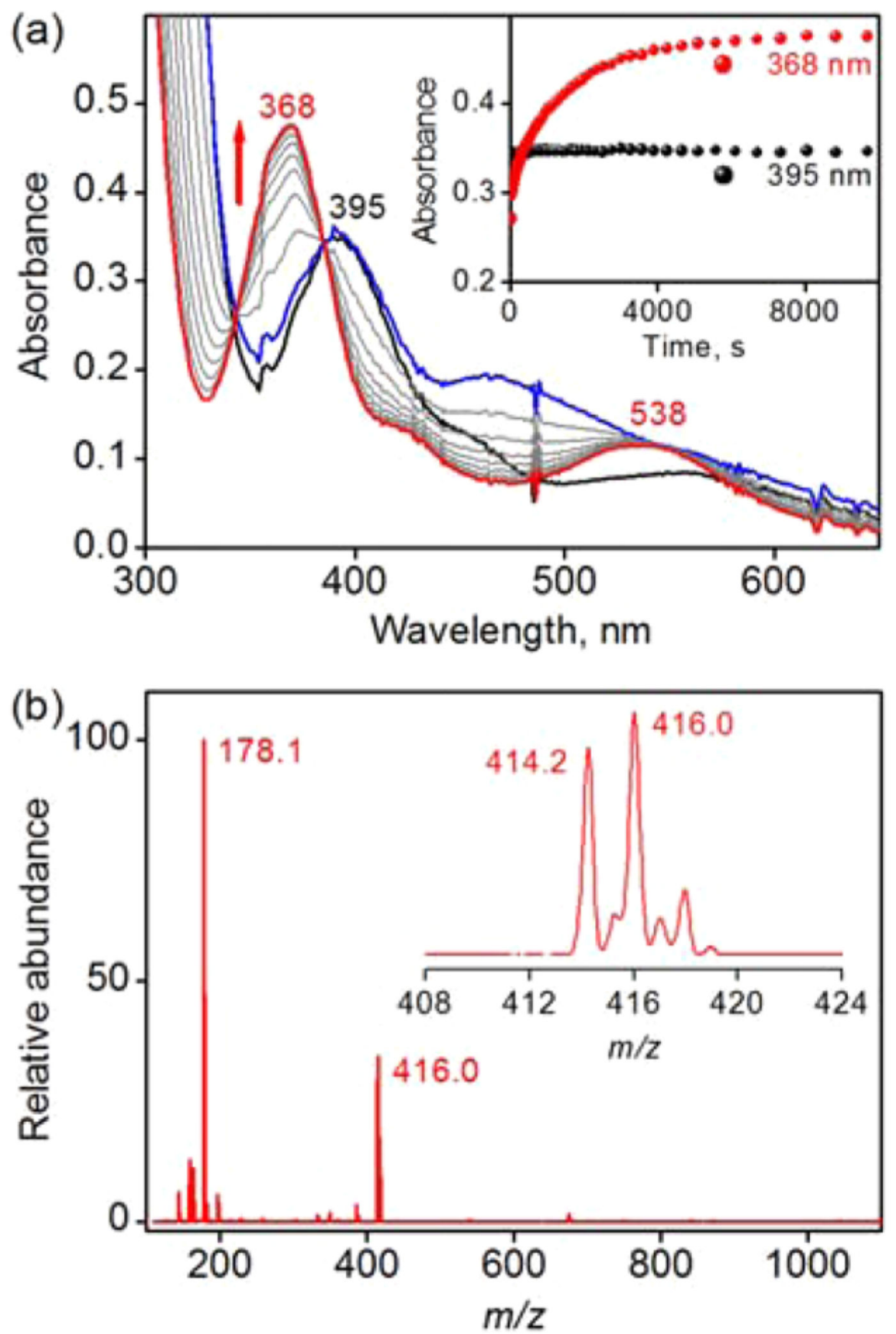

Figure 3.

(a) UV-vis spectral changes obtained in the NO-transfer from $1(0.50 \mathrm{mM}$; black line) to $\left[\left(12-\mathrm{TMC} \mathrm{Co}^{\mathrm{II}}\right]^{2+}(0.50 \mathrm{mM})\right.$ to form $\mathbf{2}$ (red line) through the intermediacy of the blue line spectrum under an $\mathrm{Ar}$ atmosphere in $\mathrm{CH}_{3} \mathrm{CN}$ at $-40{ }^{\circ} \mathrm{C}$. The blue line spectrum was confirmed to be the sum of those spectra of $\mathbf{1}(0.50 \mathrm{mM})$ and [(12-TMC)Co $\left.{ }^{\mathrm{II}}\right]^{2+}(0.50 \mathrm{mM})$. Inset: reaction time course monitored at $368 \mathrm{~nm}$ due to $\mathbf{2}$ in the NO-transfer reaction (red circles) and that monitored at $395 \mathrm{~nm}$ for natural decay of $\mathbf{1}$ (black circles). (b) ESI-MS spectrum of the reaction solution obtained in the NO-transfer reaction of 1 with [(12- 
TMC)Co $\left.{ }^{\mathrm{II}}\right]^{2+}$. The peaks at $\mathrm{m} / z=414.2,416.0$, and 178.1 correspond to [(14$\left.\mathrm{TMC}) \mathrm{Co}^{\mathrm{II}}\left(\mathrm{ClO}_{4}\right)\right]^{+}($calcd $\mathrm{m} / z=414.1),\left[(12-\mathrm{TMC}) \mathrm{Co}^{\mathrm{III}}(\mathrm{NO})\left(\mathrm{ClO}_{4}\right)\right]^{+}($calcd $\mathrm{m} / z=416.1)$, and $\left[(14-\mathrm{TMC}) \mathrm{Co}^{\mathrm{II}}\left(\mathrm{CH}_{3} \mathrm{CN}\right)\right]^{2+}$ (calcd $\left.m / z=178.1\right)$, respectively. 


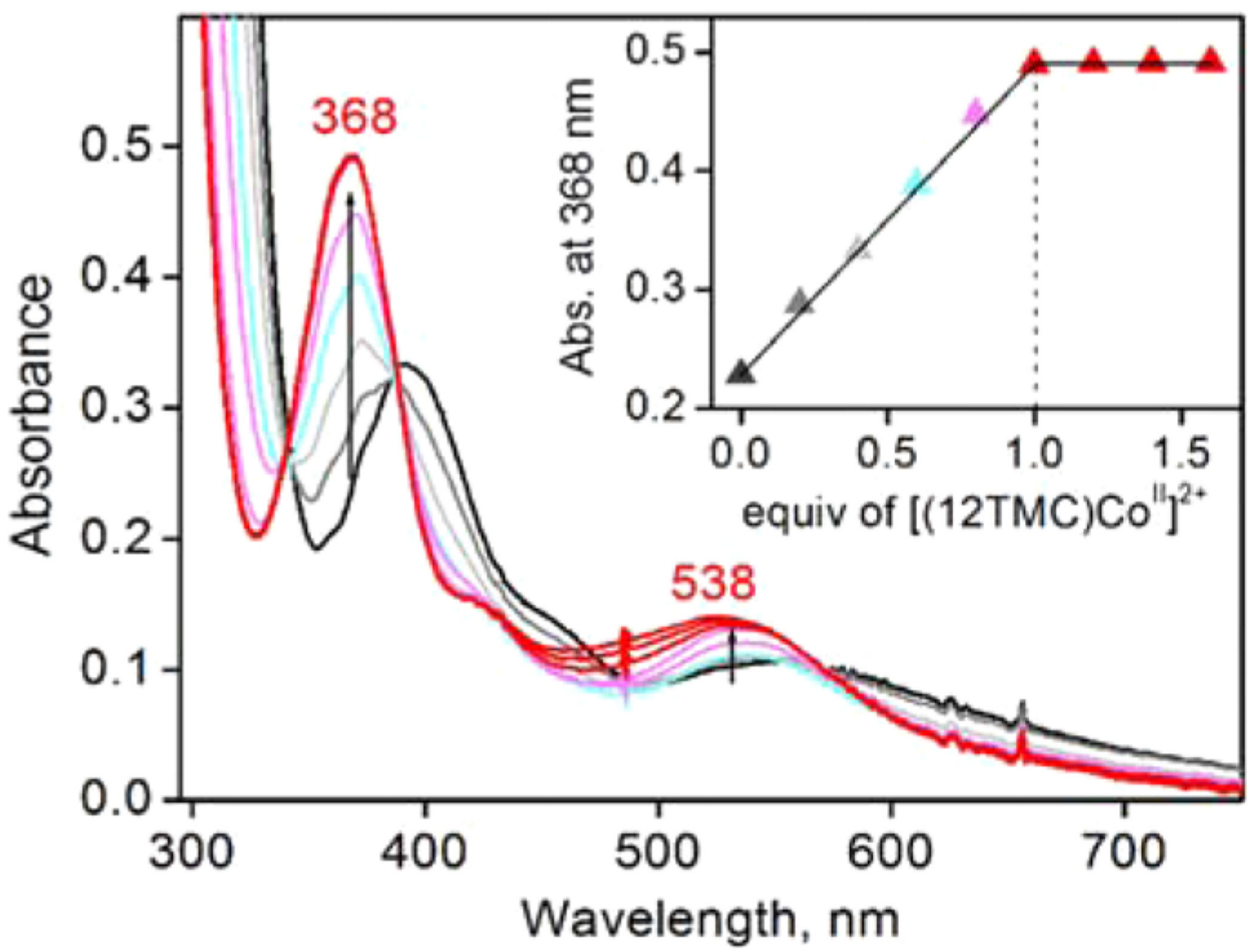

Figure 4.

UV-vis spectral changes showing the formation of 2 (red line) observed upon addition of $\left[(12-\mathrm{TMC}) \mathrm{Co}^{\mathrm{II}}\right]^{2+}$ into a solution of $\mathbf{1}$ (black line) in increments of 0.20 equiv under $\mathrm{Ar}$ atmosphere in $\mathrm{CH}_{3} \mathrm{CN}$ at $-40{ }^{\circ} \mathrm{C}$. Inset: spectral titration monitored by following the absorbance at $368 \mathrm{~nm}$ due to the formation of 2 . 


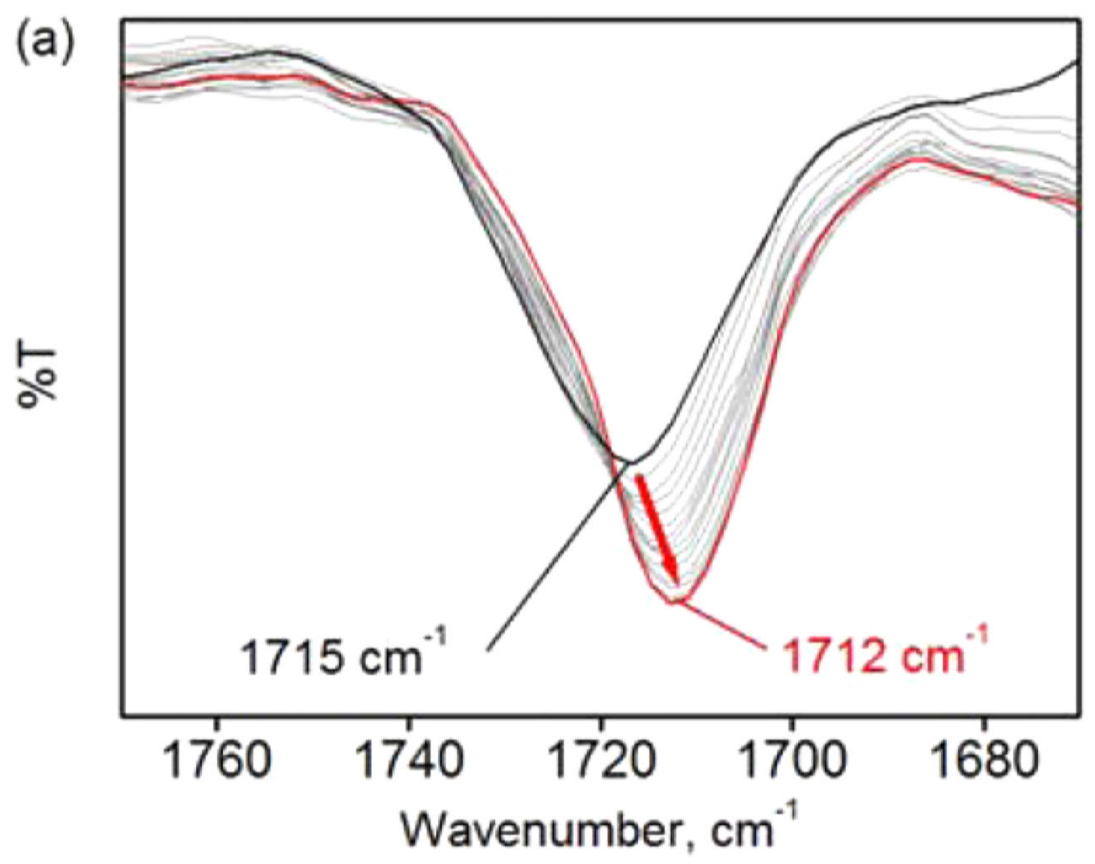

(b)

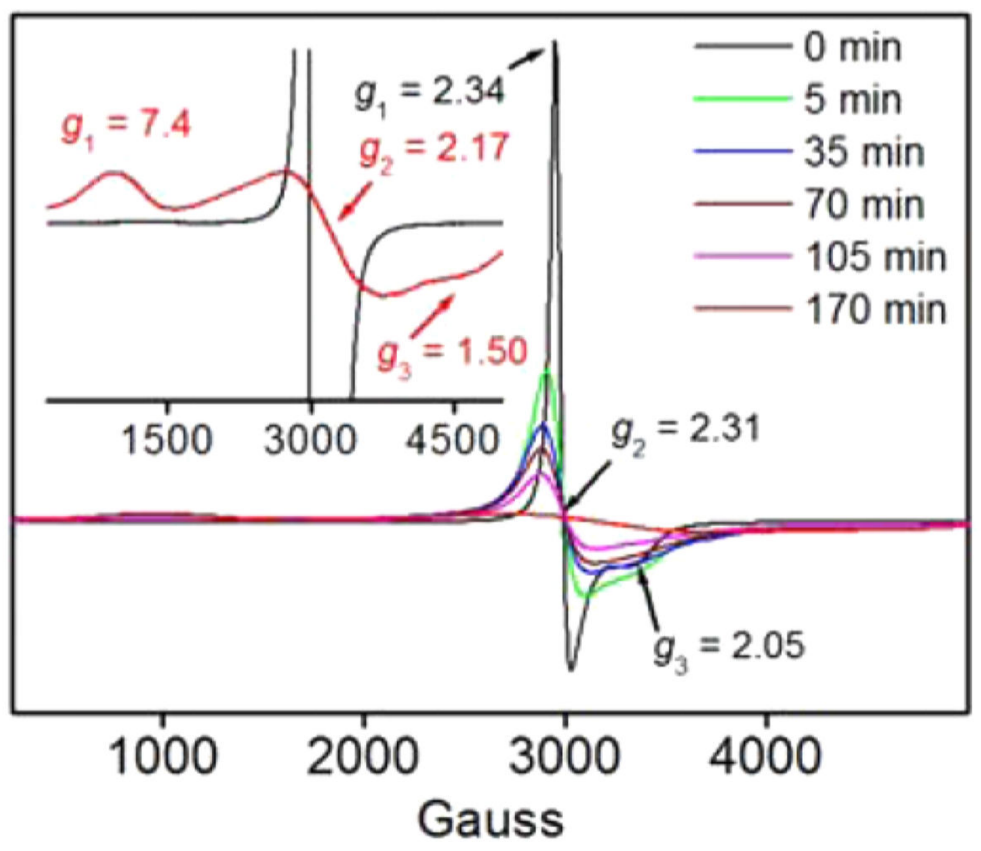

Figure 5.

(a) Solution IR spectral changes obtained in the reaction of $\mathbf{1}(3.0 \mathrm{mM})$ and [(12TMC)Co $\left.{ }^{\mathrm{II}}\right]^{2+}(3.0 \mathrm{mM})$ under an $\mathrm{Ar}$ atmosphere in $\mathrm{CH}_{3} \mathrm{CN}$ at $-40{ }^{\circ} \mathrm{C}$, showing the conversion of the NO stretching frequency due to $\mathbf{1}$ (black line) to that due to $\mathbf{2}$ (red line). (b) EPR spectral changes obtained in the reaction of $\mathbf{1}(2.0 \mathrm{mM})$ and $\left[(12-\mathrm{TMC}) \mathrm{Co}^{\mathrm{II}}\right]^{2+}(2.0$ $\mathrm{mM})$ under an $\mathrm{Ar}$ atmosphere in $\mathrm{CH}_{3} \mathrm{CN}$ at $-40{ }^{\circ} \mathrm{C}$, only showing that $\left[(12-\mathrm{TMC}) \mathrm{Co}^{\mathrm{II}}\right]^{2+}$ (black line) was converted to [(14-TMC) $\left.\mathrm{Co}^{\mathrm{II}}\right]^{2+}$ (red line) because $\mathbf{1}$ and $\mathbf{2}$ are EPR-silent $(S$ 
$=0)$. All EPR spectra were recorded at $5 \mathrm{~K}$ with different reaction times $(0,5,35,70,105$, and $170 \mathrm{~min}$ ). The inset shows the initial (black line) and final (red line) spectra expanded. 

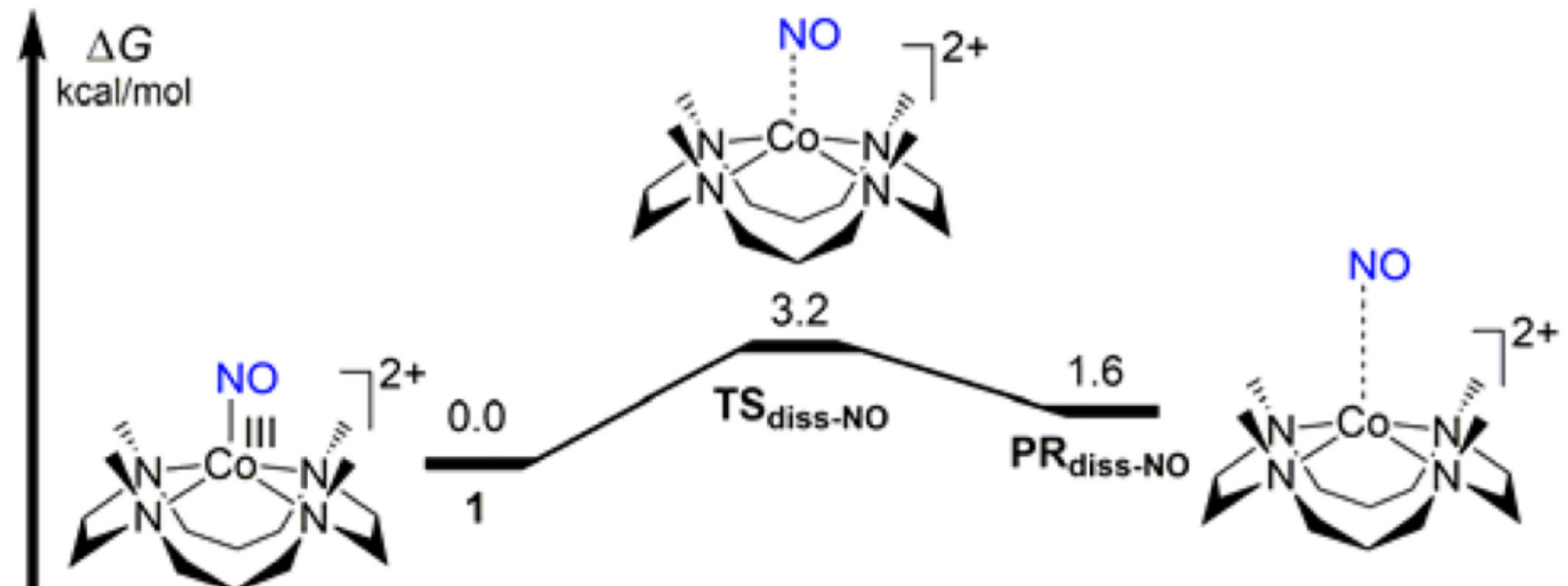

Figure 6.

DFT-calculated reaction profile of NO dissociation from $\mathbf{1}$ on singlet ground state. 


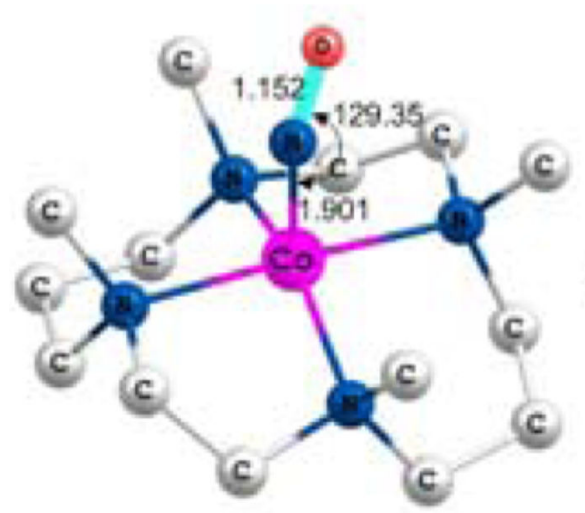

1

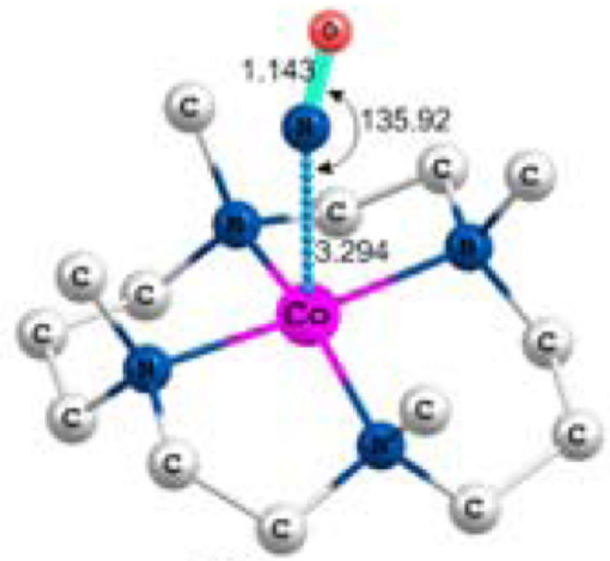

$\mathrm{TS}_{\text {diss-NO }}$

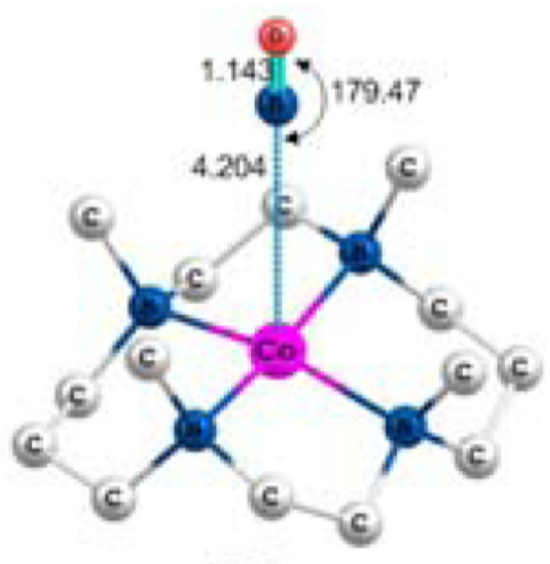

$\mathbf{P R}_{\text {diss-NO }}$

Figure 7.

DFT-optimized structures of reactant (1), transition state $\left(\mathbf{T S}_{\text {diss-NO}}\right)$, and product

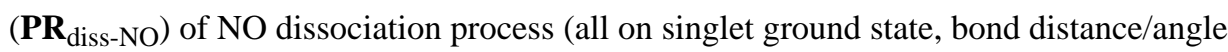
labeled in angstroms/degrees, $\mathrm{H}$-atoms are omitted for clarity). 


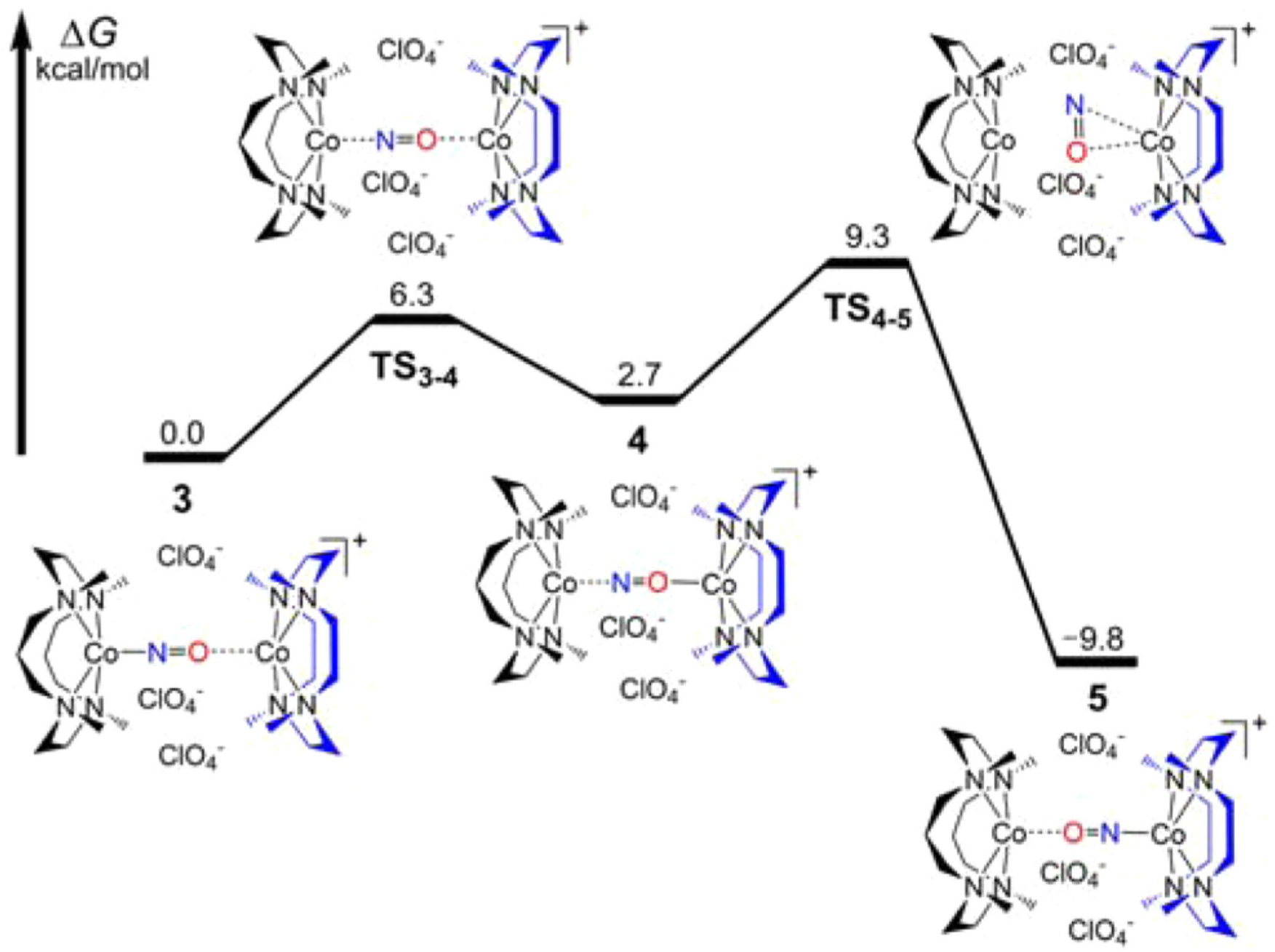

Figure 8.

DFT-calculated associative reaction profile of NO-transfer from 1 to $\left[(12-\mathrm{TMC}) \mathrm{Co}^{\mathrm{II}}\right]^{2+}$ initiated from a $\mu$-NO-bridged intermediate $\left\{\left[(14-\mathrm{TMC}) \mathrm{Co}^{\mathrm{III}}-\mathrm{NO}-\mathrm{Co}^{\mathrm{II}}(12-\mathrm{TMC})\right]\right.$ $\left.\left(\mathrm{ClO}_{4}\right)_{3}\right\}^{+}(\mathbf{3})$ on ground doublet state. 


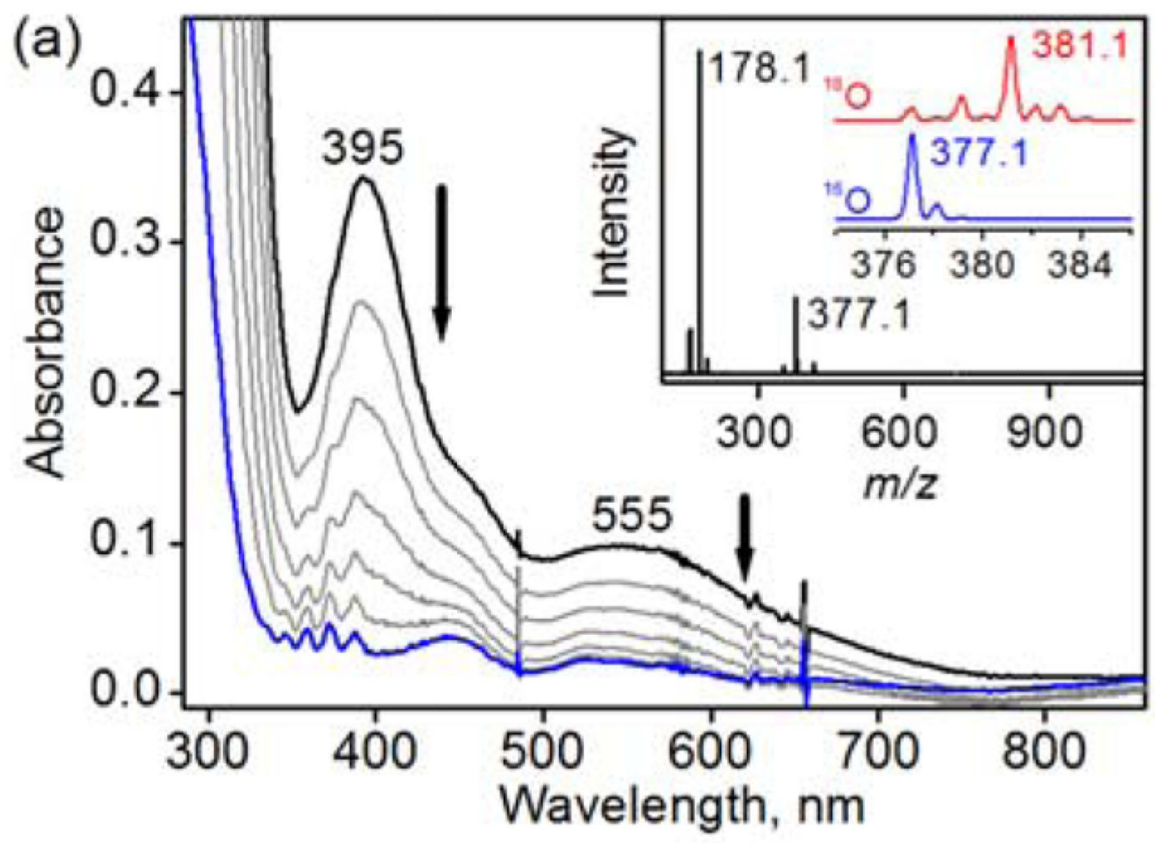

(b)

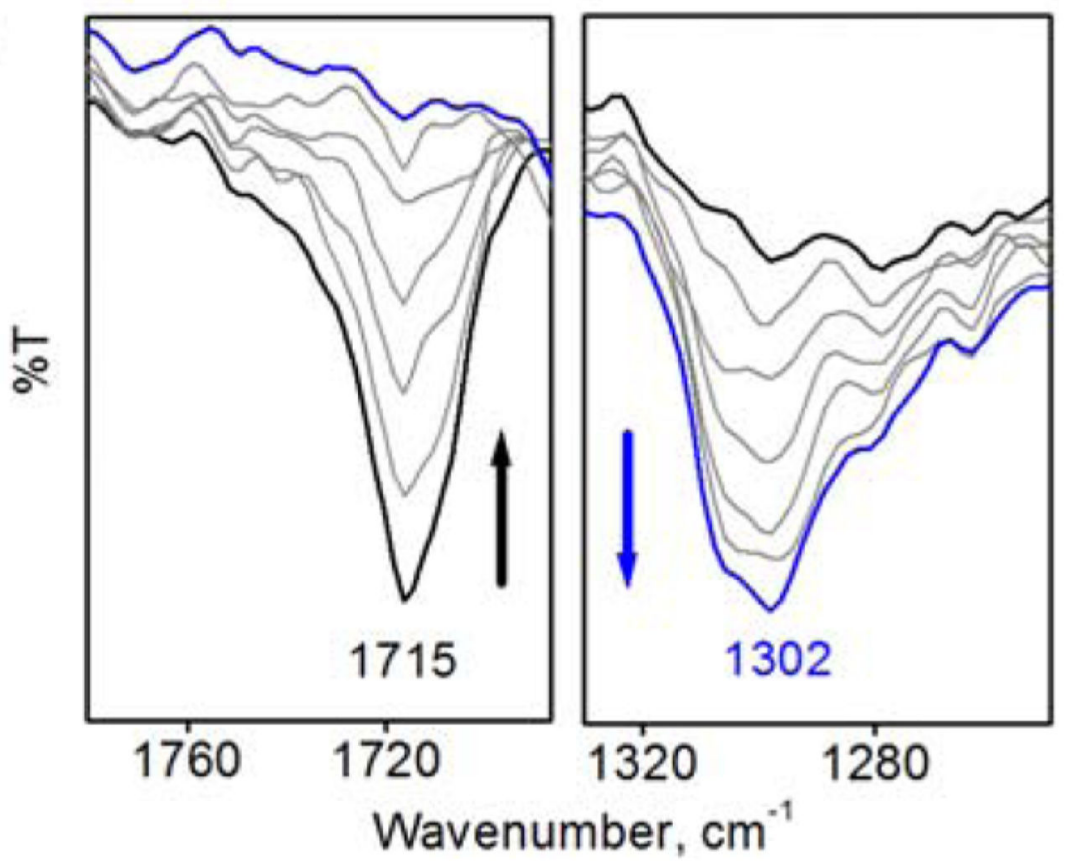

Figure 9.

(a) UV-vis spectral changes observed in the reaction of $\mathbf{1}\left(0.50 \mathrm{mM}\right.$; black line) with $\mathrm{O}_{2}$ $(0.10 \mathrm{M})$ in $\mathrm{CH}_{3} \mathrm{CN}$ at $-40^{\circ} \mathrm{C}$. Inset: ESI-MS spectrum of the complete reaction solution (black line). The peaks at $\mathrm{m} / z=377.1$ and 178.1 correspond to $\left[(14-\mathrm{TMC})-\mathrm{Co}{ }^{\mathrm{II}}\left(\mathrm{NO}_{3}\right)\right]^{+}(\mathbf{6})$ (calcd $m / z=377.1$ ) and [(14-TMC)-Co $\left.{ }^{\mathrm{II}}\left(\mathrm{CH}_{3} \mathrm{CN}\right)\right]^{2+}$ (calcd $\mathrm{m} / z=178.1$ ). Blue and red lines show the isotope distribution patterns for $\mathbf{6}^{-16} \mathrm{O}$ (blue) and $\mathbf{6}^{-18} \mathrm{O}$ (red), which were obtained from the reaction of $\mathbf{1}$ with ${ }^{16} \mathrm{O}_{2}$ and ${ }^{18} \mathrm{O}_{2}$, respectively. (b) Solution IR spectral changes for 
the disappearance of $\mathbf{1}$ (left panel, black line) and the formation of $\mathrm{NO}_{3}{ }^{-}$(right panel, blue line) observed in the reaction of $1(3.0 \mathrm{mM})$ with $\mathrm{O}_{2}(0.10 \mathrm{M})$ in $\mathrm{CH}_{3} \mathrm{CN}$ at $-40{ }^{\circ} \mathrm{C}$. 


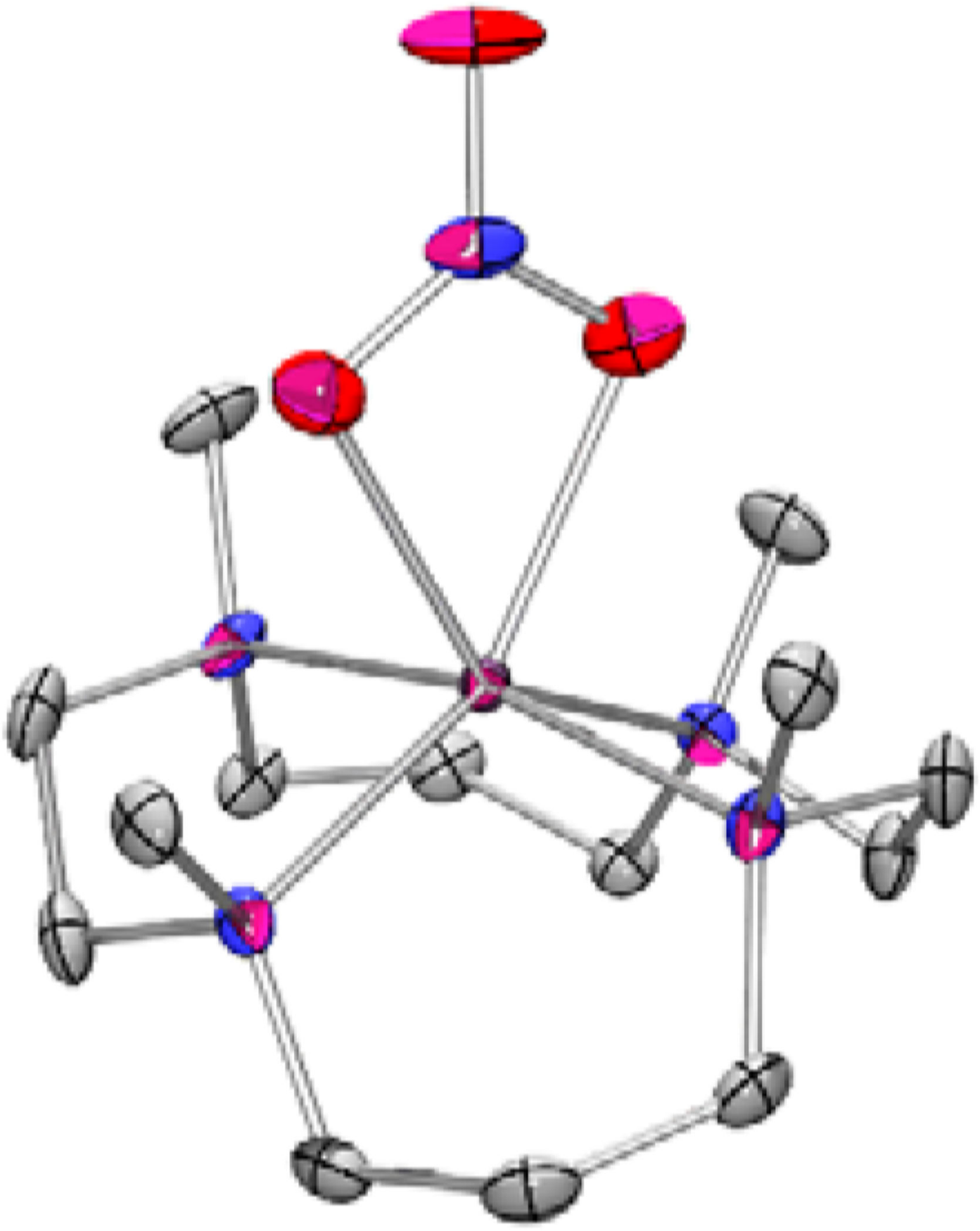

Figure 10.

ORTEP diagram of [(14-TMC) $\left.\mathrm{Co}^{\mathrm{II}}\left(\mathrm{NO}_{3}\right)\right]^{+}(\mathbf{6})$ with $50 \%$ probability thermal ellipsoids (gray, C; blue, $\mathrm{N}$; red, $\mathrm{O}$; violet, $\mathrm{Co}$ ). $\mathrm{H}$ atoms have been removed for clarity. 
(a) Dissociative pathway

$\mathrm{M}(\mathrm{NO}) \frac{k_{1}}{k_{-1}} \mathrm{M}+\mathrm{NO} \stackrel{k_{2}, \mathrm{M}^{\prime}}{\longrightarrow} \mathrm{M}+\mathrm{M}^{\prime}(\mathrm{NO})$

(b) Associative pathway

$\mathrm{M}(\mathrm{NO})+\mathrm{M}^{\prime} \rightleftharpoons \mathrm{M}(\mathrm{NO}) \mathrm{M}^{\prime} \rightleftharpoons \mathrm{M}+\mathrm{M}^{\prime}(\mathrm{NO})$

Scheme 1. 


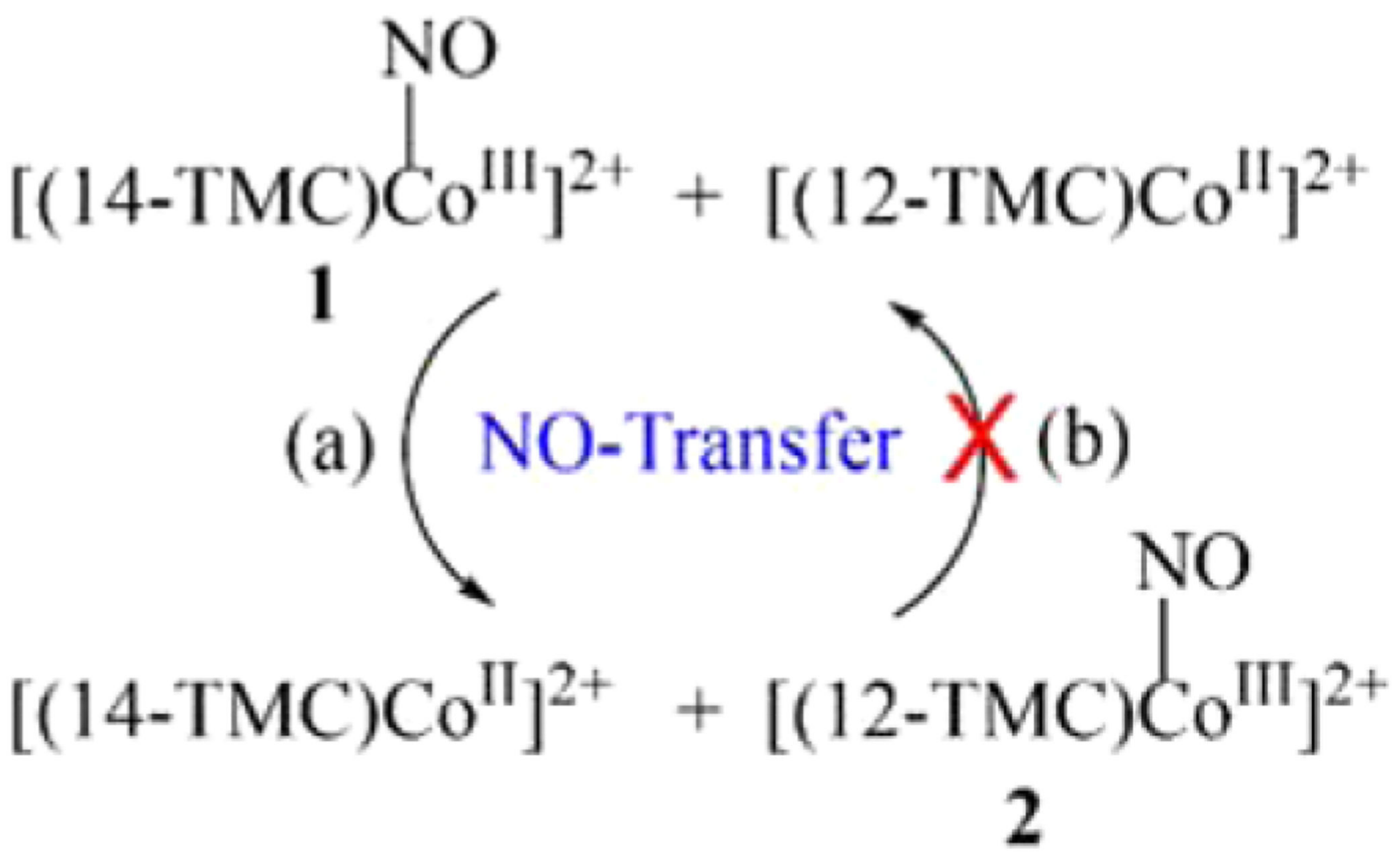

Scheme 2.

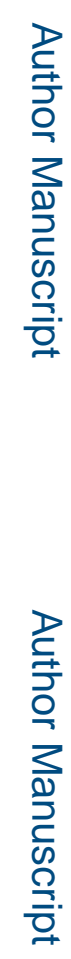




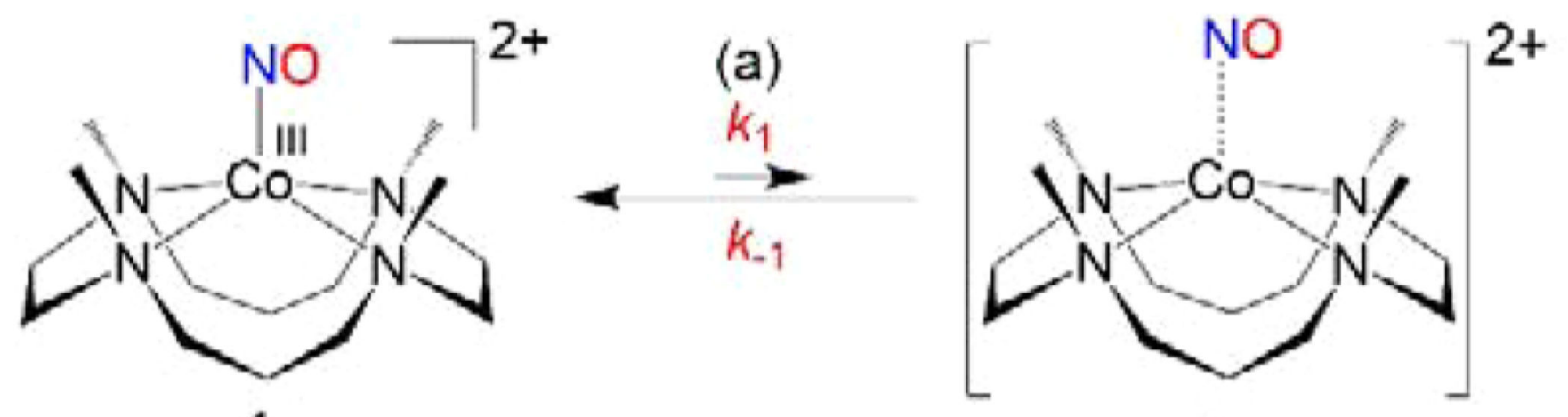

1
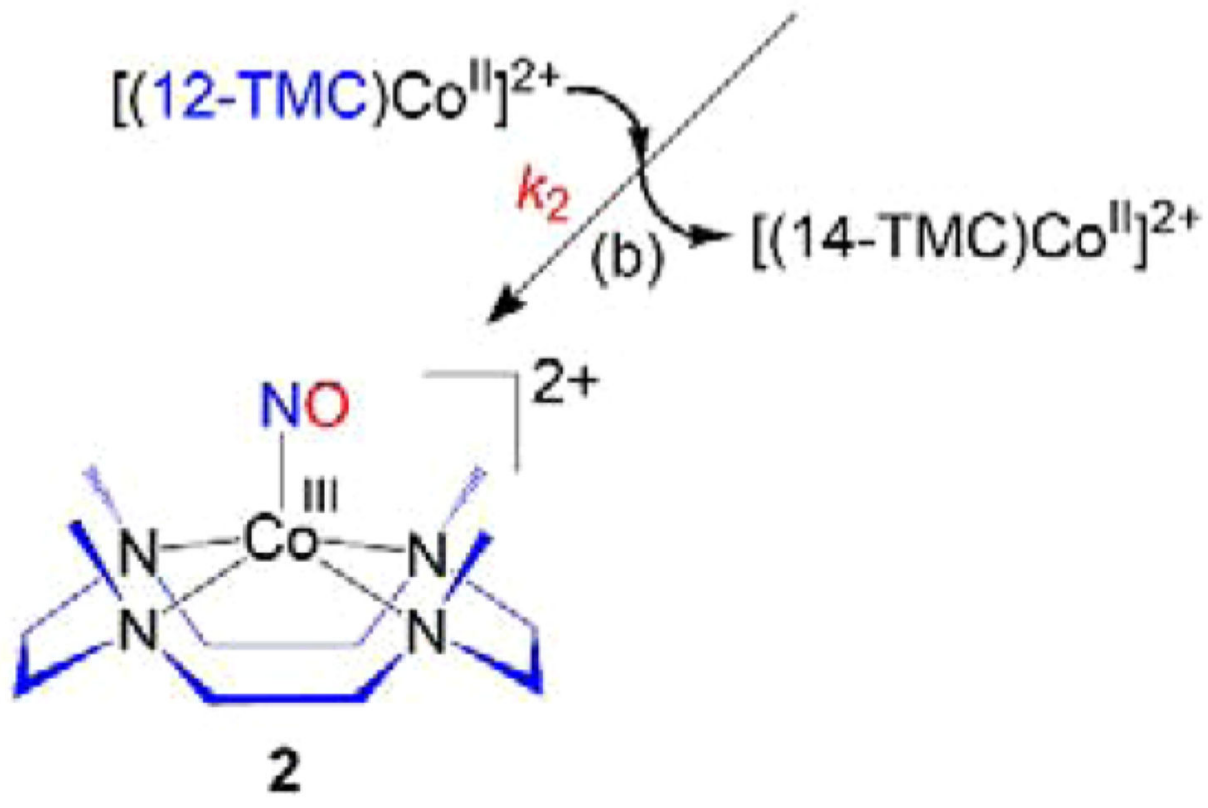

Scheme 3. 

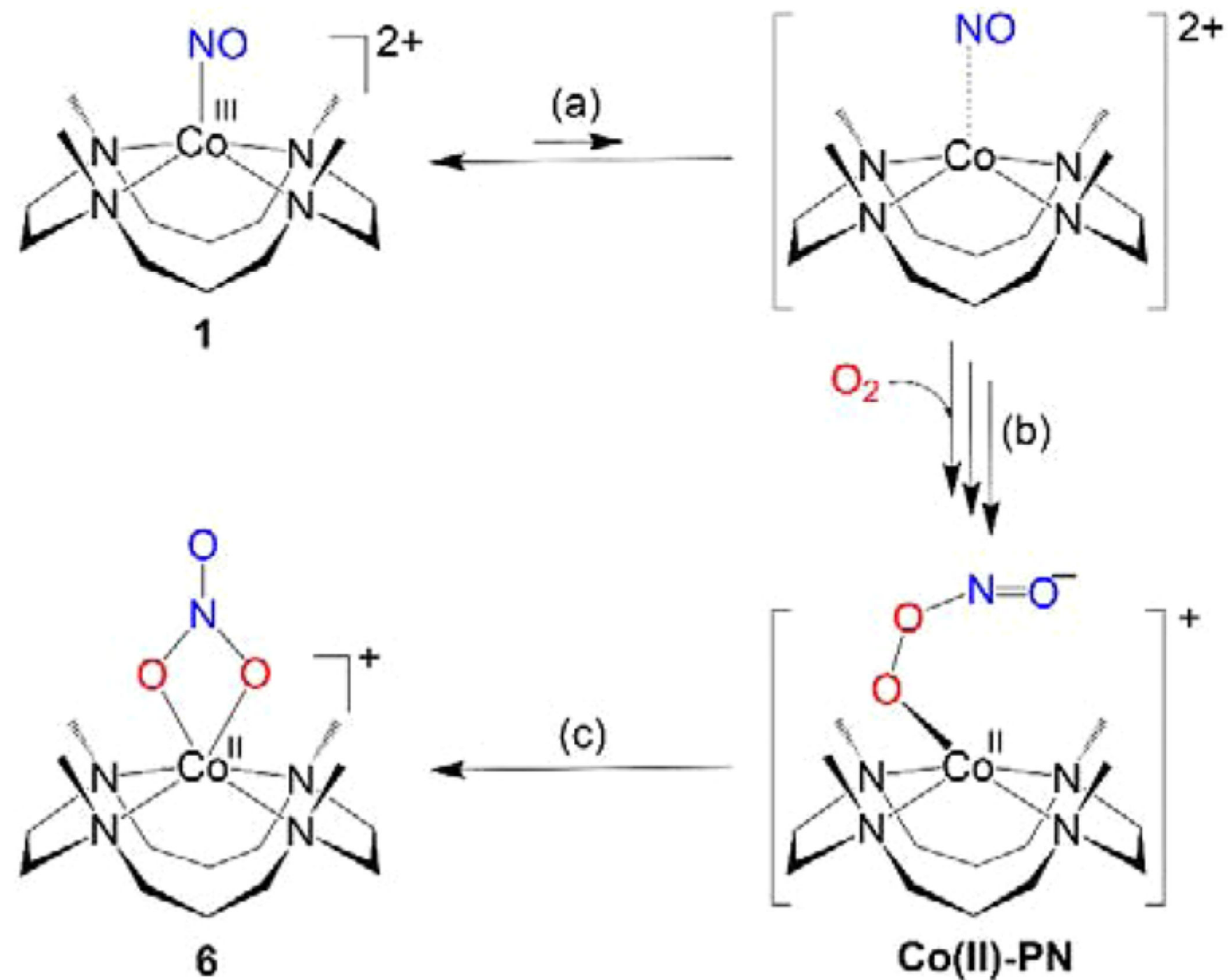

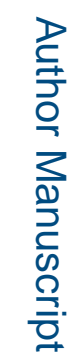

Scheme 4.

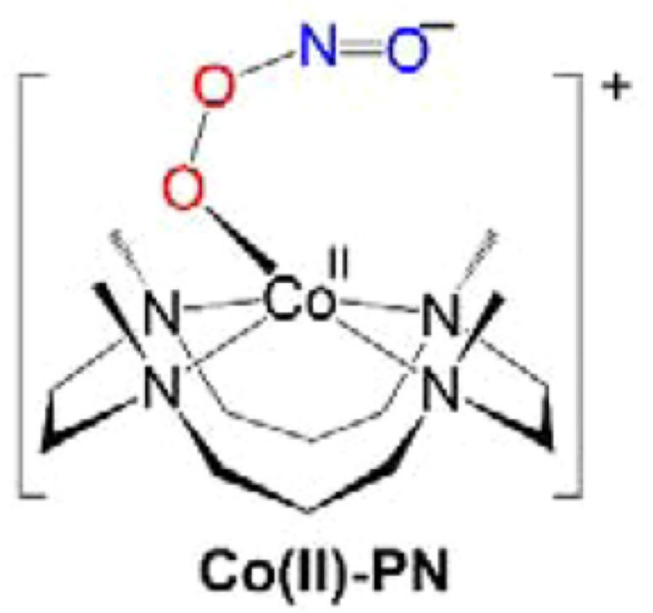

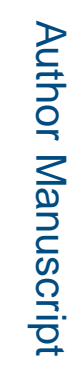



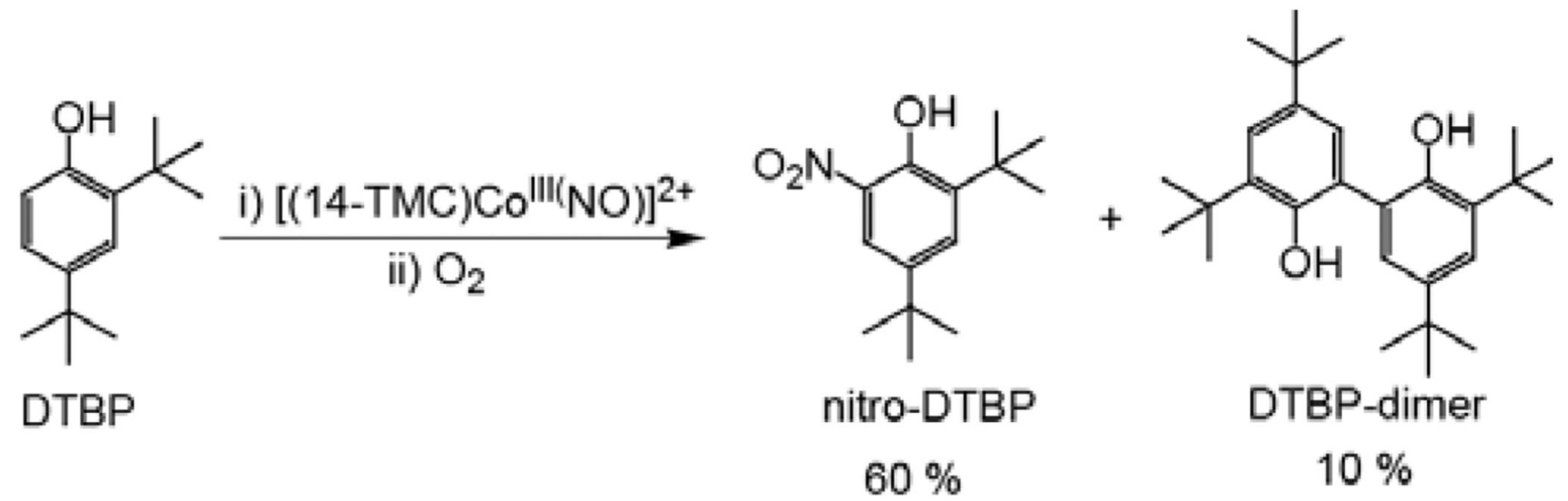

Scheme 5. 